University of Florida Levin College of Law

UF Law Scholarship Repository

Faculty Publications

Faculty Scholarship

$1-1-2005$

\title{
Beating the 'Wrap': The Agency Effort to Control Wraparound Insurance Tax Shelters
}

Charlene Luke

University of Florida Levin College of Law, lukec@law.ufl.edu

Follow this and additional works at: http://scholarship.law.ufl.edu/facultypub

Part of the Insurance Law Commons, and the Tax Law Commons

\section{Recommended Citation}

Charlene Luke, Beating the 'Wrap': The Agency Effort to Control Wraparound Insurance Tax Shelters, 25 Va. Tax Rev. 129 (2005), available at http://scholarship.law.ufledu/facultypub/343

This Article is brought to you for free and open access by the Faculty Scholarship at UF Law Scholarship Repository. It has been accepted for inclusion in Faculty Publications by an authorized administrator of UF Law Scholarship Repository. For more information, please contact outler@law.ufl.edu. 


\section{BEATING THE "WRAP": THE AGENCY EFFORT TO CONTROL WRAPAROUND INSURANCE TAX SHELTERS}

Charlene Davis Luke*

\section{TABLE OF CONTENTS}

I. INTRODUCTION

II. INSURANCE PRODUCT AND TAX BACKGROUND

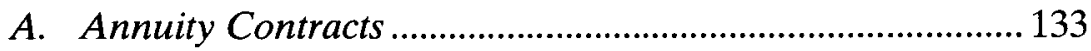

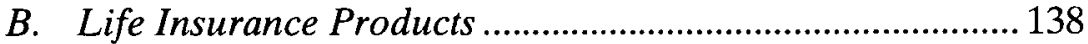

C. Inside Buildup Tax Treatment ............................................. 139

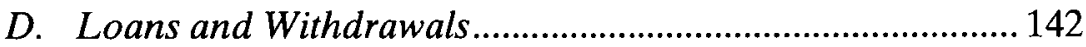

III. VARIABLE INSURANCE PRODUCTS: HISTORY OF AN

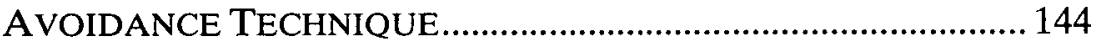

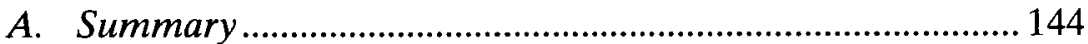

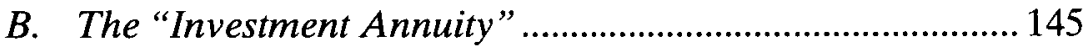

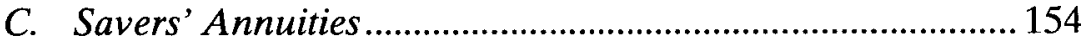

D. Mutual Fund Annuities......................................................... 159

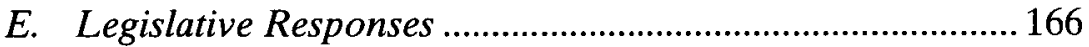

1. Life Insurance Changes................................................ 167

2. Changes to Annuity Code Provisions.............................. 169

3. Diversification Requirements for Variable

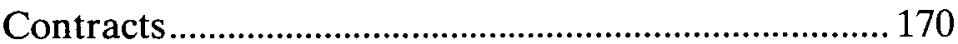

F. Hedge Fund Wrappers...................................................... 174

- Assistant Professor of Law, Florida State University. Thanks to Aviva Abramovsky, Meg Baldwin, Barbara Banoff, Debbic Bassett, Elizabeth Chorvat, Mary Crossley, Joseph Dodge, J. Clifton Fleming, Stephanie Gore, Adam Hirsch, Trevor Luke, Greg Mitchell, Andrew Pike, Jim Rossi, Mark Seidenfeld, Lois Shepard, Tommy F. Thompson, Don Weidner, and Ellen Yee for comments and encouragement. 
IV. THE EFficacy Of THE AgENCIES' Legal Framework ..... 184

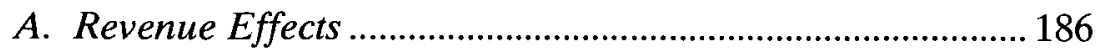

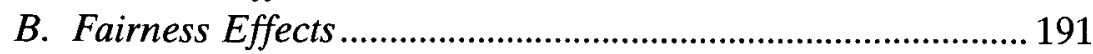

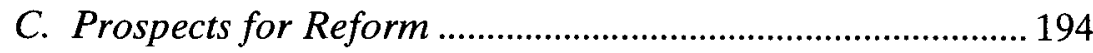

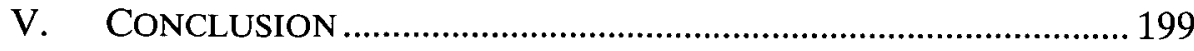

\section{INTRODUCTION}

The owners of cash value life insurance and annuity contracts have long been able to defer paying tax on the income accruing inside these products - that is, on the "inside buildup." Early insurance products provided their contract owners with only a low, guaranteed return close to the risk-free rate of return. ${ }^{2}$ Concerns about the effect of inflation on these products, however, triggered the creation in 1952 of a new insurance product: an annuity tied to investments yielding a variable, risk-related return. ${ }^{3}$ It took some time for the variable annuity to gain acceptance, perhaps because of uncertainty surrounding its classification for securities and tax law purposes. ${ }^{4}$ In 1959, the Supreme Court provided some resolution of the securities law questions, and shortly thereafter Congress signaled its decision to allow the inside buildup of variable annuities to accumulate on a taxdeferred basis.

${ }^{1}$ Although this treatment of inside buildup is well established, as Professor Pike has observed with respect to life insurance, "[t]he precise statutory basis for this exclusion is obscure." Andrew D. Pike, Reflections on the Meaning of Life: An Analysis of Section 7702 and the Taxation of Cash Value Life Insurance, 43 TAX L. REV. 491, $493 \mathrm{n} .2$ (1988). With respect to annuities, deferral is implied by section $72(\mathrm{e})$, which governs the taxation of annuity withdrawals. See infra notes $186-88$ and accompanying text; see also Richard W. Skillman, The Impact of TEFRA and the 1984 Act on the "Inside Build-up" Under Life Insurance Products, 43 N.Y.U. INST. ON FED. TAX'N 40-1, 40-30 (1985) (describing the similarly obscure origin for the deferral applying to annuities).

2 See infra notes 23,42 and accompanying text.

3 See infra notes 23-25 and accompanying text.

${ }^{4}$ For a discussion of evidence that tax law uncertainty inhibits the marketing of new types of securities, see Mark P. Gergen \& Paula Schmitz, The Influence of Tax Law on Securities Innovation in the United States: 1981-1997, 52 TAX L. REV. 119, 15762 (1997). In the case of variable insurance, both securities and tax law uncertainties were present during the first years of the product.

${ }^{5}$ See infra notes 29-36 and accompanying text. 
Beginning around 1965, taxpayers began to exploit the inconsistency arising from the difference between the treatment of variable insurance returns and the economically similar returns available outside variable insurance. ${ }^{6}$ In the tax avoidance game ${ }^{7}$ that has developed, variable contract purveyors wrap a variety of incomeproducing investments inside variable annuities or life insurance in order to defer paying tax on the inside buildup. The contract marketers also try to minimize insurance features of the contracts (e.g., the mortality bet) to maximize the contract holder's control over the income-producing assets underlying the contract, and to provide contract holders with access to the inside buildup without triggering

${ }^{6}$ See Noël B. Cunningham \& Deborah H. Schenk, Taxation Without Realization: A "Revolutionary" Approach to Ownership, 47 TAX L. REV. 725, 751 (1992) (discussing the complexity arising from the failure to treat economically similar transactions identically); David M. Schizer, Balance in the Taxation of Derivative Securities: An Agenda for Reform, 104 CoLUM. L. REv. 1886, 1895 (2004) (discussing consistency).

Because life insurance companies have also received numerous tax benefits, there has generally been no offsetting detriment, and so no symmetry of treatment for the parties to the variable insurance. See Howard Stecker et al., Separate Account Products, Part II: Tax Rules Along the Insurance Product Continuum, TAX NoTES TODAY (Aug. 5, 1998) (LEXIS, FEDTAX lib., TNT file, elec. cit., 98 TNT 150-29) (describing how separate account investment income is generally excluded from insurance company taxable income); see also Alvin C. Warren, Jr., Financial Contract Innovation and Income Tax Policy, 107 HARV. L. REV. 460, 471 (1993) ("Electivity of tax treatment might be tolerable ... if a tax-advantaged choice for one taxpayer were always coupled with a tax-disadvantaged consequence for another taxpayer.").

7 George K. Yin, Getting Serious About Corporate Tax Shelters: Taking a Lesson From History, 54 SMU L. REv. 209, 216-17 (2001) (using the phrase "Tax Avoidance game" to describe the efforts of taxpayers to outmaneuver changes in the law); see also David M. Schizer, Sticks and Snakes: Derivatives and Curtailing Aggressive Tax Planning, 73 S. CAL. L. REv. 1339, 1344 (2000) (using the term "planning option" to describe how well-advised taxpayers restructure transactions for favorable tax treatment).

This article uses the traditional distinction between tax avoidance and tax evasion. See Joel Slemrod \& Jon BakiJa, Taxing Ourselves: A Citizen's Guide TO THE DeBATE OVER TAXES 171 (3d ed. 2004). This distinction has been expressed by the aphorism: "The poor evade, and the rich avoid ..." Id. at 179. That is, the poor, unable to afford high-priced help, enter into transactions that are more clearly fraudulent, fail to report income, and/or overstate deductions or credits. The rich, on the other hand, have the ability to structure transactions for which there is at least a technical argument that they are legal. Id. David Cay Johnston's recent book, which contains explanations of some tax avoidance techniques of the wealthy, alludes to this distinction in its title. David Cay Johnston, Perfectly Legal: The CoverT Campaign to Rig Our Tax System to Benefit the Super Rich - And Cheat EVERYBODY ELSE (2004). 
tax liabilities. In the most recent iteration of this "wraparound" insurance gambit, insurance companies - with the likely complicity of sophisticated, wealthy taxpayers - wrapped private placement hedge fund interests inside variable insurance products in order to defer tax on the ordinary income thrown off by such interests. ${ }^{8}$ Thus, hedge fund wrappers were being used primarily to convert ordinary income into tax-sheltered income.

Although Congress has at times intervened in the history of this game, to good effect, ${ }^{10}$ it has left intact the tax subsidy for variable insurance inside buildup and thereby the incentive for taxpayers to exploit this preference. ${ }^{11}$ Congress has provided the Treasury and the Internal Revenue Service (Service) with some authority to keep variable insurance products from becoming ready, tax-preferred substitutes for commonplace, taxable investments. ${ }^{12}$ Exercising this authority, however, has required the tax agencies to distinguish proper risk-based returns from improper risk-based returns. ${ }^{13}$ The fundamental economic similarity of all risk-based returns makes this

${ }^{8}$ See infra Part III.F.

${ }^{9}$ Derivative instruments have similarly been used to convert ordinary income hedge fund returns to long-term capital gains. See Lee A. Sheppard, Constructive Ownership of a Bag of Dead Cats, 81 TAx Notes 407, 407-08 (Oct. 26, 1998) (describing this technique). Congress enacted Internal Revenue Code (Code) section 1260 to curtail the ability to use derivatives to effectuate conversion transactions. Its enactment did make derivative-based conversion transactions more difficult, but taxpayers quickly moved to insurance contracts as a derivative substitute. David $\mathbf{M}$. Schizer, Frictions as a Constraint on Tax Planning, 101 ColuM. L. REV. 1312, 1368 (2001); see also Schizer, supra note 6, at 1935 (comparing hedge fund derivatives and wraparound insurance).

${ }_{10}$ See infra Part III.E.

${ }_{11}$ In order to end the technique, Congress would need to take a more radical approach to variable insurance products. Indeed, wraparound insurance is only one of the tax avoidance techniques making use of insurance companies and their products. See Lee A. Sheppard, Hedge Funds, Hogs, and PORC, TAX NOTES TODAY (Nov. 1, 2002) (LEXIS, FEDTAX lib., TNT file, elec. cit., 2002 TNT 214-20) (discussing technique in which hedge funds "disguise themselves as offshore insurance companies").

${ }^{12}$ See infra notes 198-200 and accompanying text; see also Lee A. Sheppard, Hedge Funds in Insurance Wrappers, TAX NOTES TODAY (Sept. 23, 2002) (LEXIS, FEDTAX lib., TNT file, elec. cit., 2002 TNT 185-4) (describing the agencies' responses to wraparound insurance as their effort "to hold the line on the extent to which life insurers become unregulated purveyors of tax-sheltered investment products").

${ }^{13}$ See Skillman, supra note 1 , at 40-39 (explaining that the agencies have been able to find "no basis for a meaningful distinction between 'good' and 'bad' variable annuities"). 
line-drawing exercise ultimately impossible. ${ }^{14}$

The tax agencies are frequently hampered by flaws in the statutory base from which they must operate. One tax agency strategy - the one used in the case of variable insurance products - is to raise the cost of a particular avoidance technique so that it becomes less attractive to most (if not all) taxpayers. Using this method, the agencies have been able to arrive at a legal framework that has been fairly effective at cutting back a particular iteration of the shelter, but it is a framework that has also permitted the periodic flourishing of new forms of wraparound insurance. As a result of its ability to resolve immediate fairness concerns raised by a particular version of the shelter, the agencies' framework may diminish the prospect of broader legislative reform of the underlying systemic flaw. ${ }^{15}$

Part II of this article provides a brief introduction to the insurance terminology and tax treatment necessary to an understanding of wraparound insurance contracts. ${ }^{16}$ Part III provides a detailed history of the wraparound insurance technique and the government's responses to it. ${ }^{17}$ Readers familiar with variable insurance products and the history of the wraparound insurance tax shelter may wish to begin with Part IV, which assesses the effectiveness of the agencies' responses and discusses alternative approaches that may better further the goal of fundamental reform. Part V is the conclusion.

\section{INSURANCE PRODUCT AND TAX BACKGROUND}

\section{A. Annuity Contracts}

Annuity contracts are structured in two phases. ${ }^{18}$ First, during the

14 See David A. Weisbach, Line Drawing, Doctrine, and Efficiency in the Tax Law, 84 CORNELL L. REV. 1627, 1627 (1999) (positing that "one can analyze doctrinal rules in disparate areas of the tax law as a single class of problems - line-drawing problems").

15 See Daniel Shaviro, When Rules Change: An Economic and Political ANALYSIS OF TRANSITION RELIEF AND RETROACTIVITY 93 (2000) (describing a "widespread consensus... that society would benefit from the use of a more comprehensive tax base").

${ }^{16}$ This article addresses non-qualified variable life insurance and annuities. Although some of the early wraparound products were structured as group plans and the tax agencies' actions had effects on those plans, qualified plans are now policed through a different set of regulatory and legislative requirements.

${ }_{17}$ The primary administrative tool is known as the "investor control doctrine," described infra Part III.

${ }^{18}$ This describes deferred annuities. Immediate annuities are also available. 
accumulation phase, the contract holder pays premiums and investment income builds up in the contract. In a fixed annuity, this income builds up at a low rate guaranteed by the insurance company. Following the accumulation phase, if the contract holder does not elect to receive a lump sum payment, ${ }^{19}$ the annuity contract enters the annuitization phase during which the investment buildup (including income that continues to accrue during annuitization) is turned into a stream of periodic payments. ${ }^{20}$ Annuitization has long been described as "the reverse of life insurance" ${ }^{\text {"1 }}$ because the mortality bet made in the case of an annuity tied to a life contingency is that the contract holder will have a long life rather than die prematurely. ${ }^{22}$

Concerns that inflation could erode the benefits of fixed, low-rate annuity contracts ${ }^{23}$ prompted the Teachers Insurance and Annuity

Under these types of annuities, there is no accumulation phase. Instead, the contract holder deposits a lump sum that is immediately turned into an income stream.

19 See Bridget O'Brian \& Vanessa O'Connell, Annuity Sales May Suffer in Clinton Plan to Tax an Exchange Between Accounts, Wall St. J., Feb. 4, 1998, at C1 (stating that "only $1 \%$ of annuity holders" annuitize).

${ }^{20}$ This payment stream may be made over the remainder of the annuitant's life. The payment stream may also be (and most commonly is) tied to a term of years. See Tommy F. Thompson, Nonqualified Deferred Variable Annuities: A Product in Search of a Coherent Theory, 79 N.D. L. REv. 439, 450-51, 456-57, 473-74 (2003) (discussing fixed term annuities and life-contingent annuities). Annuities tied to a life contingency generally may not be surrendered for cash in order to prevent individuals from using new information about their particular longevity to personal advantage. See id. at 457 n. 82 .

${ }^{21}$ See S.C. Cyzio, Your InSurance: Its Problems ANd Their Solution 128 (1934) (describing annuitization as "the reverse of life insurance"); William Vickrey, Insurance Under the Federal Income Tax, 52 YALE L.J. 554, 567 (1943) (using the description "obverse of insurance").

${ }^{22}$ A character in a Jane Austen novel quipped, "people always live for ever when there is any annuity to be paid them...." JANE AUSTEN, SENSE AND SEnsibility 42 (Tony Tanner ed., Penguin Books 1986) (1811); see K. Raymond Clark, TAXATION OF LIFE INSURANCE AND ANNUITIES 25 (1941) (explaining that with annuitization, "the company risks longevity instead of premature death").

Some annuities do provide a guaranteed return of investment at death or some other type of minimum death guarantee. These contract riders come at the price of higher fees, and unlike life insurance death proceeds, this type of death benefit may not be excluded from income under Code section 101. I.R.C. $\$ 101$; see Thompson, supra note 20 , at $481-83$ (describing overpricing of death benefits sold with variable annuities).

${ }^{23}$ Typically, the insurance company would invest in conservative investments such as bonds and mortgages. The contract would then guarantes a rate similar to that available on these investments. See Carol V. Calhoun, Tax Law and the Nonqualified Variable Annuity, 41 TAX LAW. 765, 765 (1988) (describing use of 
Association of America (TIAA) to establish in 1952 the first variable annuity product, which was funded through the College Retirement Equities Fund (CREF). ${ }^{24}$ This first variable product was only offered in conjunction with the fixed rate group insurance plans offered by TIAA. Shortly after TIAA-CREF introduced the variable annuity, three small companies began selling individual variable annuities. ${ }^{25}$ Variable annuity products altered the fixed annuity in two fundamental ways: "First, premiums collected [were] invested to a greater degree in common stocks and other equities. Second, benefit payments var[ied] with the success of the investment policy."26 Although fixed annuities had always had some investment flavor, the returns were tied to contractually guaranteed rates. Thus, the variable annuity product introduced risk-based returns into the staid world of insurance, ${ }^{27}$ and those investment risks were borne by the contract

conservative investments by insurance companies); Tamar Frankel, Variable Annuities, Variable Insurance and Separate Accounts, 51 B.U. L. REV. 177, 182 (1971) (same).

${ }^{24}$ In 1951, TIAA published a study demonstrating that "over a long period of time, the average performance of equity securities far exceeded the rise in the cost of living." Frankel, supra note 23, at 177.

${ }^{25}$ SEC v. Variable Annuity Life Ins. Co. of Am., 359 U.S. 65, 95 (1959) (Harlan, J., dissenting); see also Joseph W. Bartlett, Variable Annuities: Evolution and Analysis, 19 STAN. L. REV. 150, 152 (1966) (discussing development of the first commercial variable annuity company, the Variable Annuity Life Insurance Company of America); Shirley Scheibla, Out of Retirement: After Years in the Courts, Variable Annuities are Back in Business, BARRON's, Feb. 22, 1965, at 3 (describing the development of variable annuities).

${ }^{26}$ Variable Annuity Life Ins. Co. of Am., 359 U.S. at 69. For more on the development of early variable annuities, see Bartlett, supra note 25, at 151-53; J. Edward Day, A Variable Annuity is Not a "Security," 32 Notre Dame LAw. 642, 66264 (1957); Frankel, supra note 23, at 177; Anthony M. Vernava, Tax Planning for the Not-So-Rich: Variable and Private Annuities, 11 WM. \& MARY L. REV. 1, 14-17 (1969); Paul A. Johnston, Teachers Insurance Firm to Offer Equities Plan, BARRON's, Nov. 12, 1951, at 25 (describing TIAA's proposal to issue variable annuities).

${ }^{27}$ There was significant opposition to the new products coming both from the mutual fund industry and from more conservative insurance companies, including Metropolitan Life. These groups fought to keep states from enacting the legislation necessary to permit variable annuities. For example, the first commercial variable annuity company was organized in Washington, D.C., where enabling legislation was not required. See Frankel, supra note 23, at 177-78 (describing opposition to the early variable annuity products) (citations omitted); Paul A. Johnston, Variable Annuity Opposed for Lack of Safeguards, BARRoN's, Sept. 19, 1955, at 30 (same); John C. Perham, "Met" vs. "Pru": The Variable Annuity Touches Off a Financial Free-For-All, BARRON's, Jan. 23, 1956, at 3 (describing "the first so-called variable annuity policy ever offered to the general public"). 
holder rather than by the insurance company. ${ }^{28}$

At first, the primary legal question raised by these annuities was whether they were insurance products regulated by the states or "securities" subject to regulation by the Securities and Exchange Commission (SEC) ${ }^{29}$ In 1959, the Supreme Court alleviated some of the uncertainty surrounding this issue by holding for the SEC in Securities and Exchange Commission v. Variable Annuity Life Insurance Co. $(V A L I C){ }^{30}$ The Court held that it was necessary to distinguish between fixed and variable annuities in order to preserve the SEC's general oversight of the securities market. ${ }^{31}$ This result

28 See Armon Glenn, Variable Annuities: More Investors are Taking the Plunge, BARRON's, Jan. 17, 1977, at 11, 29 (describing the shift of investment risk to the contract holder).

In the case of both fixed and variable annuities tied to a life contingency, the insurance company bears the mortality risk that the annuitant will live longer than expected. See also Day, supra note 26, at 676 (explaining the assumption of mortality risk by the life insurance company); Joel H. Goldberg \& Thomas P. Lemke, Disclosure of Variable Annuity Tax Contingencies: Revenue Ruling 81-225 and the Tax Equity and Fiscal Responsibility Act of 1982, 15 CONN. L. REV. 433, 437 n.10 (1983) (same). If the annuity payment stream is tied to a fixed number of years, the mortality risk is shifted away from the insurance company. See Thompson, supra note 20 , at 451 ("A variable annuity without life contingencies places both [mortality and investment] risks on the policyholder.").

${ }^{29}$ The SEC brought suit to enjoin the sale of these products until they came into compliance with federal securities law. See Variable Annuity Life Ins. Co. of Am., 359 U.S. at 66; see also Frankel, supra note 23, at 179-80. In order to prevail, the SEC had to demonstrate that the variable annuity was not "insurance." The McCarranFerguson Act provided that "[n]o Act of Congress shall be construed to invalidate, impair or supersede any law enacted by any State for the purpose of regulating the business of insurance ...." Variable Annuity Life Ins. Co. of Am., 359 U.S. at 67 (quoting 15 U.S.C. $\$ 1012$ (b)).

${ }^{30}$ Id. at 65 . Numerous articles have been devoted to this opinion, the lower court decisions, and the general issue of whether variable annuities should be classified as securities. See, e.g., Bartlett, supra note 25 (describing the VALIC decision, as well as subsequent SEC rulings and court cases about the treatment of variable annuities as securities); Day, supra note 26, at 678; Frankel, supra note 23, at 178-80.

${ }^{31}$ The majority opinion explained:

[W] would not undertake to freeze the concepts of "insurance" or "annuity" into the mold they fitted when these federal Acts were passed. But we conclude that the concept of "insurance" involves some investment risk-taking on the part of the company. The risk of mortality, assumed here, gives these variable annuities an aspect of insurance. Yet it is apparent, not real; superficial, not substantial.... For in common understanding "insurance" involves a guarantee that at least some fraction 
raised the question of whether the inside buildup of variable annuities would receive the same tax deferral as that granted to the inside buildup of fixed annuities.

Following VALIC, Congress enacted the Life Insurance Company Income Tax Act of 1959 (1959 Act), ${ }^{32}$ which "explicitly recognized variable annuities as annuity contracts," thereby affirming that tax deferral would be afforded to the inside buildup of variable annuities. ${ }^{33}$ The 1959 Act, using the product in VALIC as a template, defined a variable contract narrowly as one for which payment was "computed on the basis of... the investment experience of the company issuing the contract." ${ }^{34}$ In 1962, Congress enacted legislation permitting the return on variable annuities to be calculated based on separate accounts, ${ }^{35}$ which allowed existing insurance companies more easily to create variable products. The legislation also facilitated the development of the first wraparound insurance product because the legislation was interpreted to allow the marketing of variable

of the benefits will be payable in fixed amounts.

Variable Annuity Life Ins. Co. of Am., 359 U.S. at 71. This language could be (and was) construed to exempt from SEC regulation variable annuity products in which the insurance company retained some of the investment risk, such as by offering a minimum guarantee. The United Benefit Life Insurance Company, for example, created a modification of the variable annuity that allowed policyholders a guaranteed return of at least part of the premiums paid; this return was available even prior to maturity. The Supreme Court intervened again and held that this arrangement still constituted a security. SEC v. United Benefit Life Ins. Co., 387 U.S. 202 (1967); see Vernava, supra note 26, at 20 (describing United Benefit Life); Ronald J. Axelrod, Note, Variable Annuity Held To Be Subject to Federal Securities Regulation, 17 Buff. L. REV. 495 (1967) (same); Note, Insurance-Deferred Annuity Policy Which Guarantees Return of 100 Per Cent of Net Premiums Not Subject to SEC Regulation, 20 VAND. L. REV. 670, 673-74 (1967) (critiquing appellate court decision in United Benefit Life).

${ }^{32}$ The 1959 Act primarily dealt with issues of insurance company taxation unrelated to the VALIC decision and that are beyond the scope of this article. For a discussion of the 1959 Act's effect on insurance companies, see Keith A. Tucker et al., Federal Taxation of Life Insurance Companies: The Evolution of a Tax Law Responding to Change, 37 Sw. L.J. 891, 894-96 (1984). The 1959 Act was made retroactive, thus it also applies to 1958 . Id. at $894 \mathrm{n} .13$.

${ }^{33}$ Calhoun, supra note 23, at 768 .

${ }^{34}$ Id. at 769 . The 1959 Act's definition was a temporary measure that was later made permanent in 1961. See Walter D. Vinyard, Jr., IRS Annuity Rulings Contradict Public Policy on Retirement Savings, 36 Bus. LAw. 1765, 1768-69 (1981).

${ }^{35}$ See Shirley Hobbs Scheibla, Threat to Variable Annuities: The IRS Soon Will Issue a New Ruling on Tax Deferral, BARRoN's, June 29, 1981, at 11, 24 (describing 1962 legislation permitting separate accounts). 
annuities tied to personalized accounts. ${ }^{36}$

\section{B. Life Insurance Products}

Life insurance provides economic protection against the death of the insured. There are two basic types of life insurance contracts. First, term life is a policy that is in force only for a specific period, typically one year. ${ }^{37}$ Term life is pure insurance. ${ }^{38}$ That is, the premium is used entirely to pay for mortality charges (and other expenses), and thus there is no premium available to yield an investment return. ${ }^{39}$ Because mortality charges increase with age, the price of term life insurance becomes prohibitive in later years. ${ }^{40}$ The second type, cash value life insurance, solved this problem by allowing policyholders to pay premiums that in part are for insurance charges and in part are to create an investment fund to be used in later years to provide protection. ${ }^{41}$

${ }^{36}$ See id. at 24 (discussing the 1963 creation of the first company to sell wraparound contracts).

The 1959 Act also imposed a company-level 28 percent tax on the capital gains realized inside the separate accounts of commercial, non-qualified variable annuities. See Skillman, supra note 1, at 40-37 to -38 (describing the company-level tax under the 1959 Act); Glenn, supra note 28, at 30 (same). This company-level tax may have slowed the sale of standard variable annuities but appears to have had little impact on aggressive, tax avoidance variations on the variable annuity. Skillman, supra note 1 , at 40-38; see also infra note 87; Richard Goode, Policyholders' Interest Income from Life Insurance Under the Income Tax, 16 VAND. L. REV. 33, 39 (1962) (discussing general impact of the 1959 Act on insurance companies).

The tax on capital gains was put in place in order to ensure greater parity between mutual funds and variable annuities. See Skillman, supra note 1, at 40-37 to 38; see also Johnston, supra note 27, at 31-32 (describing fears of mutual funds that variable annuities "would have a tremendous tax advantage" if no capital gains tax applied to the insurance companies).

${ }^{37}$ Renewable term is available, as are term policies, for periods of ten years or more.

${ }^{38}$ Because there is not an investment component, the deferral of tax on inside buildup is not available. See infra Part II.C.

${ }^{39}$ This is simplified. Premiums for term life, particularly for contracts renewable over a period of several years, likely reflect some discount reflecting time value of money returns. See Tommy F. Thompson, The Tax Advantaged Treatment of Life Insurance, 4 TAX L.J. 27, 33 \& n.17 (1989). However, the convention has long been to describe term policies as having little or no investment element. See CyzIO, supra note 21, at 105-06 (describing term life as "pure insurance"); Goode, supra note 36, at 36 ("Term insurance policies ... involve little saving and interest earnings.").

40 See Thompson, supra note 39, at 35-36.

${ }^{41}$ See CyzIO, supra note 21, at 106-09 (describing the development of cash value 
Fixed, cash value life insurance policies provided a low, guaranteed return. ${ }^{42}$ Individual, commercial variable life insurance policies were not introduced until 1976, much later than variable annuities. ${ }^{43}$ Like variable annuities, variable life insurance contracts are designed to provide risk-based returns for which the policyholder bears the investment risk. The insurance company continues to bear the mortality risk. ${ }^{44}$

\section{Inside Buildup Tax Treatment}

As already discussed briefly in Part I, qualifying forms ${ }^{45}$ of life insurance and annuities allow the owner of the contract to defer paying taxes on the inside buildup until the buildup is withdrawn. ${ }^{46}$

policies). At a certain point in time, the policy is not providing "insurance" protection at all. Instead, the death benefit is paid from an investment reserve. See Goode, supra note 36, at 34-35 (describing declining insurance and increasing investment aspects of cash value life insurance).

${ }^{42}$ See CYZIO, supra note 21 , at 108 (stating that a typical rate of return on cash value life insurance "is usually $3 \%$ or $31 / 2 \%$ "); Goode, supra note 36 , at $35 \mathrm{n} .3$ (describing assumed rates of return in 1959 as ranging from 2 percent to $2 \frac{1}{2} 2$ percent).

43 See VARIABle CONTRACTS 36-37 (1995) (describing the first commercial variable life insurance contracts to be sold in the United States); Glenn, supra note 28, at 30-31 (same).

Group variable life was available somewhat earlier, in approximately 1972. Glenn, supra note 28, at 30-31 (describing development of group variable life policies); see also Dana L. Thomas, Despite Equity Funding - Outlook for Insurance Companies Has Never Been Brighter, BARRoN's, Apr. 16, 1973, at 17-18 (same); Dana L. Thomas, More Aggressive Policy - Life Insurance Companies are Busily Diversifying, Expanding, BARRON's, Apr. 10, 1972, at 13 (describing initial proposals for variable life plans).

Another important development in life insurance products was the creation in 1979 of the first flexible premium contract - known as "universal life." See VARIABLE CONTRACTS, supra, at 56 . Under these contracts, a policyholder is not required to pay a set premium at a particular time interval. Thus, a policyholder could choose to pay one very large premium at the outset. Universal life contracts were combined with variable contracts to form variable universal life contracts. Currently, a specific Code provision prevents single-premium policies from receiving the full tax benefits afforded level-payment cash value life insurance. I.R.C. $\$ 7702 \mathrm{~A}$.

${ }^{44}$ See Thompson, supra note 39 , at 52 (explaining the shift of investment risk to the policyholder).

${ }^{45}$ See infra Part III.E.1 (describing definition of life insurance).

${ }^{46}$ In addition to the tax deferral on inside buildup, the Code treats distributions from life insurance policies as first being return of premium rather than inside buildup, thus allowing some deferral even when the policyholder has cash in hand. In the case of life insurance, income tax deferral for inside buildup may become a permanent exclusion if the policy is held until death of the owner. I.R.C. $\S 101$. 
For example, if the owner pays a net premium of $\$ 100$ into a qualifying life insurance policy that provides for a $3 \%$ return, the $\$ 3$ earned that year will not be taxed to the owner currently but will instead only be taxed if it is withdrawn before the owner's death. In contrast, if the same individual had invested $\$ 100$ in a ten-year certificate of deposit $(\mathrm{CD})$ providing the same rate of return, the $\$ 3$ would be taxed currently - whether or not withdrawn during that year. ${ }^{47}$ Of course, purchasing life insurance is more costly than purchasing a $\mathrm{CD}$. The insurance policy owner will need to have invested more than $\$ 100$ in order to cover the mortality charge and other administrative expenses for that year. ${ }^{48}$

The ostensible reason for the tax preference granted inside buildup is to create an incentive for individuals to provide for their loved ones at death or for themselves during retirement, ${ }^{49}$ but it is far from clear whether these tax benefits have had this intended effect. First, underinsurance continues to be a widespread problem. ${ }^{50}$ In addition, term life insurance does not have any significant investment component to which the beneficial treatment for inside buildup could attach, nor is the purchase of term life insurance deductible, and yet, term life insurance is the most common type of insurance. ${ }^{51}$ Finally, insurance companies likely capture some of the tax benefit for inside

There is a narrow exception for death benefits paid on an insurance contract that has been transferred for "valuable consideration." I.R.C. §101(a)(2). Life insurance proceeds are, however, included in the gross estate of a decedent for estate tax purposes if the decedent possessed any "incidents of ownership" in the insurance policy at the time of his death. I.R.C. $\S 2042$; see Joseph M. Dodge, Substantial Ownership and Substance Versus Form: Proposals for the Unification of Federal Estate and Gift Taxes and for Taxation of Generation-Skipping Transfers, 1976 U. ILL. L.F. 657 (discussing the reform of the taxation of transferred property).

${ }^{47}$ See Rev. Rul. 66-44, 1966-1 C.B. 94. This example is simplified. The amount of the inclusion generally depends on application of the rules for original issue discount. I.R.C. \$1272; Internal Revenue Service, Publication 550: INVESTMENT INCOME AND EXPENSES, at 13-14 (2003).

${ }^{48}$ During later policy years, inside buildup may be used to cover such fees. Although these expenses would not be deductible if paid for out of pocket, the inside buildup used to pay such fees is permanently excluded from income since it can never be distributed. See Goode, supra note 36, at 38 (describing this effect); Pike, supra note 1 , at 536-37 (same).

${ }^{49}$ See Department of the Treasury, Report to The Congress on the TAXATION OF Life Insurance Company Products 2 (1990).

so See Kyle D. Logue, The Current Life Insurance Crises: How the Law Should Respond, 32 CuMB. L. REv. 1, 26 (2001) (describing studies on underinsurance).

${ }^{51}$ See Pike, supra note 1 , at 530 (noting the "irrational inverse relationship between the need for insurance protection and the distribution of tax benefits"). 
buildup. $^{52}$ Variable insurance contracts have notoriously high fees that cut into the rate of return, ${ }^{53}$ which renders variable insurance unsuitable for those in lower tax rate brackets. ${ }^{54}$ Thus, the deferral for inside buildup is a tax preference supported by flimsy justifications. ${ }^{s s}$ When the tax avoidance techniques designed to exploit the deferral are also considered, the deferral is a subsidy not worth the cost.

Although various government players have at times recommended the wholesale repeal of the deferral on inside buildup, ${ }^{56}$

${ }_{52}$ See Lee A. Sheppard, Rationalizing the Taxation of Financial Intermediaries, 73 TAX NOTES 733, 735 (Nov. 11, 1996) (describing how insurers "claw[] back a lot of the tax benefit through hefty fees and opaque pricing").

${ }^{53}$ See, e.g., Kathy Chu, Variable Annuities: A Bad 'Wrap'?, W All ST. J., Oct. 4, 2004, at R7 (explaining that deferred variable annuities "have attracted a litany of criticism because of their high fees"); Jonathan Clements, Defending a MuchMaligned Investment: When Variable Annuities Make Sense, WALL ST. J., Oct. 20, 2004, at D1 (describing the "sky-high fees" of variable annuities).

${ }^{54}$ A similar phenomenon has been well documented in the case of tax-exempt bonds. See, e.g., MYron S. Scholes ET Al., TAXes and Business Strategy: A PlANNING APPROACH 118-20 (3d ed. 2005) (discussing implicit taxes on lightly taxed investments); Daniel N. Shaviro, The Story of Knetsch: Judicial Doctrines Combating Tax Avoidance, in TAX STORIES 318 (Paul Caron ed., 2003) (using tax-exempt bonds to illustrate "the tendency in some circumstances for market forces to eliminate through price changes any after-tax benefit").

${ }^{55}$ See David F. Bradford, The Case for a Personal Consumption Tax, in WHAT Should Be TAXED: INCOME OR EXPENDITURE? 75, 90-91 (Joseph A. Pechman ed., 1980) (highlighting the deferral for inside buildup as one of the complex problems of the income tax); Cunningham \& Schenk, supra note 6, at 798-99 (questioning why life insurance products are treated differently from OID obligations); Goode, supra note 36 , at 33 (discussing the inconsistency in treatment between life insurance and other investment types); Pike, supra note 1, at 578 (arguing that "the investment income credited to cash value life insurance contracts should be taxed currently"); Vickrey, supra note 21 , at 561 ("[T]he savings part of the life insurance contract should obviously be treated as any other form of savings ....").

${ }^{56}$ For example, proposals to curtail the benefits arising from deferral for inside buildup were floated by the Carter, Reagan, George H.W. Bush, and Clinton administrations. See Jefrrey H. Birnbaum \& Alan S. Murray, Showdown at GuCCI GulCh: Lawmakers, Lobbyists, and THE UNLIKELy TRIUMPH OF TAX REFORM 84-85 (1987) (describing Reagan administration proposals); Bridget O'Brian, Clinton Plan for Annuities is Clarified, WALl ST. J., Feb. 9, 1998, at C18 (describing Clinton administration's proposal to "make exchanges between variable annuities taxable, as well as transfers between variable and fixed annuities"); Vanessa O'Connell, Clinton's Plan on Annuities is Nearly Dead, WALl ST. J., Mar. 9, 1998, at $\mathrm{C} 20$ (describing Clinton as "the third president in a row to attempt to alter annuities' tax status"); Ellen E. Schultz and Karen Slater, Buyers Guide: This May Be Last Chance to Purchase Annuities, but Use Caution, WALl ST. J., Feb. 5, 1992, at C1 (describing Bush administration proposal to strip most individual annuities of tax 
such legislation has never been implemented. ${ }^{57}$ The insurance lobby is powerful. ${ }^{58}$ Congressional efforts have instead largely focused on restricting the deferral for inside buildup to particular types of life insurance and annuity contracts. ${ }^{59}$ Thus, because Congress has so far been unable (or unwilling) to remove entirely the preference for inside buildup, ${ }^{60}$ a gray zone has persisted that is conducive to the development of aggressive tax avoidance schemes.

\section{Loans and Withdrawals}

The amount of benefit available from the tax deferral on inside buildup depends on the contract holder's ability to refrain for multiple years from drawing down cash value through partial or full surrender. ${ }^{61}$ The principal way to tap into the cash value of a life insurance or annuity policy without actually making a withdrawal is to

deferral).

${ }^{57}$ See Pike, supra note 1, at 578 (arguing that Congress is unlikely to take action "because the preferential tax treatment of cash value life insurance is based more on politics than on tax policy analysis").

${ }^{58}$ One of the fights over government proposals to tax inside buildup was described in BIRNBAUM \& MURRAY, supra note 56, at 85 :

Full-page advertisements in Time, Newsweek, People, U.S. News \& World Report, and Sports Illustrated carried sets of three postcards intended for mailing to each reader's senators and representatives. Insurance agents were given similar postcard sets, which they passed out to their clients. A videotape, entitled David and Goliath, Round Two, was used to whip up opposition to the tax plan among the life insurance industry's many minions, and offered step-by-step instructions on how to personally lobby members of Congress. ... As a result, Congress was deluged by postcards from voters, with members receiving more than a million pieces of mail on the arcane subject during the first half of 1985.

See also Charles Gasparino, Annuities' Tax Status Is Stable, for Now, WALl ST. J., June 22, 1998, at C24 (discussing the power of the insurance lobby); Sheppard, supra note 12 ("[T] he life insurance industry lobby is formidable ....").

${ }^{59}$ See infra Part III.E for a discussion of these congressional reforms.

${ }^{60}$ Less radical legislative changes might also be effective. See Thompson, supra note 20 , at $508-20$ (suggesting proposals that would create a stronger distinguishing line between variable annuities and other investments).

${ }^{61}$ Partial surrender or withdrawal of cash value life insurance became widely available only in the late 1970s with the introduction of universal life. See VARIABLE CONTRACTS, supra note 43, at 60 (describing introduction of partial withdrawal). As described infra at Part III.B, investment annuities, which were variable annuities designed to exploit the deferral on inside buildup, allowed for partial withdrawals. See Vinyard, supra note 34, at 1768 (describing partial annuity redemptions). 
take out a loan secured by the cash value. ${ }^{62}$ Loans made against the cash value of annuities were received on a tax-free basis until 1982 when Congress enacted a provision requiring that all loans, pledges, or assignments of annuity cash value be treated the same as withdrawals. $^{63}$ Loan proceeds secured by the cash value of life insurance, however, continue to be received tax-free. ${ }^{64}$

Prior to the 1982 legislation, withdrawals of cash values of both annuities and life insurance were taxed on the assumption that investment in the contract was withdrawn first. Thus, only the excess of the accumulated withdrawa's over contract investment was taxed. ${ }^{65}$ This first-in, first-out ("FIFO") treatment allowed for a greater period of deferral on inside buildup. While withdrawals from annuities (other than distributions received as annuitization payments) are now taxed on an income first, investment last basis, life insurance withdrawals still receive the favorable FIFO treatment. ${ }^{66}$

${ }^{62}$ Additionally, if the loan interest were deductible, a taxpayer could run a nice tax arbitrage machine. See Vickrey, supra note 21, at 564 n.20 (describing a technique in which a taxpayer borrows on a single premium policy, takes a deduction for interest paid, uses the loan proceeds to purchase another policy, and enjoys deferral on any interest earned on policy reserves); see also Shaviro, supra note 54, at 313 (detailing the story of an individual who tried and failed at using a similar scheme). In 1942, Congress restricted the ability of taxpayers to deduct interest on indebtedness used to purchase life insurance. For the current version of this rule, see I.R.C. $\$ 264$. However, the general effectiveness of this provision is in doubt. See Vickrey, supra note 55 , at $564 \mathrm{n} .20$ (describing the expectation that the "provision would prove even less effective than has the parallel provision denying a deduction for interest paid on indebtedness incurred to carry tax exempt bonds").

${ }^{63}$ See infra Part III.E.2.

64 See Pike, supra note 1, at 534-36 (critiquing the ability to take tax-free loans on cash value life insurance).

${ }^{65}$ See Goldberg \& Lemke, supra note 28, at 451 (describing the pre-TEFRA rules for annuities); Pike, supra note 1, at 534-36 (criticizing the investment-first rule for life insurance); see also Putting Together a Portable Pension, Bus. WK., May 11, 1981, at 142 (describing the tax advantages of the first-in, first-out rule for annuities).

Annuitization payments are subject to a different tax regime. In general, a portion of the payment is considered a tax-free return on investment while another portion is taxable return on investment. I.R.C. $\$ 72(\mathrm{~b})$. The ratio of the taxed to untaxed portion has varied over time. For discussion on the taxation of regular annuity payments during different time periods, see J. BLAKE LOWE \& JOHN D. Wright, SElling Life INSURANCE Through A TAX APPROACH 67 (1936); Calhoun, supra note 23, at 766 n.4; Vernava, supra note 26, at 10-11; and Vickrey, supra note 21 , at 568-70.

${ }^{66}$ See infra Part III.E.2. In addition, contract holders may be able to access inside buildup by constructing a hedge outside the contract that would lock in the investment gain inside the contract and provide cash to the policyholder. See infra 


\section{VARIABLE INSURANCE PRODUCTS: HISTORY OF AN AVOIDANCE TECHNIQUE}

\section{A. Summary}

As described above in Part II, near-perfect conditions for the formation of a tax shelter involving variable annuities prevailed in the early 1960s. Much of the uncertainty surrounding the SEC's treatment of these products had been resolved. ${ }^{67}$ Congress had sanctioned tax deferral on inside buildup and allowed returns to be tied to segregated funds rather than to company-wide performance. ${ }^{68}$ Loans provided easy access to inside buildup, and withdrawals were taxed on a favorable, investment-out-first basis. ${ }^{69}$ Three prominent wraparound annuity products were marketed between 1965 and 1981: the investment annuity, the savers' annuity, and the mutual fund annuity.

As described in greater detail below, in response to these products, the tax agencies developed three requirements that variable contracts must meet in order to receive favorable tax treatment. First, contract holders are generally prohibited from having too many incidents of ownership with respect to the assets underlying the variable contract. Second, contract holders are prohibited from allocating premiums directly to publicly available investments. Finally, contract holders may only allocate premiums to diversified investments. $^{70}$ The first requirement applies general tax ownership standards ${ }^{71}$ to the variable insurance context. The second is a sourcing rule prohibiting direct allocation to publicly available investments and is intended to prevent contract holders from allocating premiums to investments they could own outside the variable contract. Similarly,

notes 268-73 and accompanying text.

${ }^{67}$ Scheibla, supra note 25 , at 3 (describing the removal of securities law "legal roadblocks").

${ }_{68}$ See supra notes 34-36 and accompanying text.

69 See supra Part II.D.

${ }^{70}$ See infra Part III.E.3.

7 The distinction between "standards" and "rules" has been the subject of numerous law review articles. See, e.g., Louis Kaplow, Rules Versus Standards: An Economic Analysis, 42 DUKE L.J. 557 (1992); see also Avery Weiner Katz, The Economics of Form and Substance in Contract Interpretation, 104 COLUM. L. REV. 496, 515 (2004) (describing the numerous ways in which this distinction between rules and standards has been framed); David A. Weisbach, Comment on The Tax Shelter Battle, in ThE CRISIS in TAX Administration 30, 35-36 (Henry J. Aaron \& Joel Slemrod eds., 2004) (discussing the significance of standards in tax law). 
the diversification requirement (which Congress has codified) is meant to make it difficult for taxpayers to create synthetically inside the variable contract an investment they could own outside the contract. The first two requirements are referred to together as the "investor control" doctrine.

Beginning in 1982, Congress enacted legislation intended to curb the investment orientation of insurance products. For example, Congress limited access to annuity inside buildup by imposing withdrawal penalties. ${ }^{72}$ Congress also codified the diversification requirement, and in doing so provided that diversification could be attained by looking-through to the assets of qualifying investment entities underlying variable contracts. ${ }^{73}$ As a result, instead of counting a mutual fund underlying a variable contract as a single asset, the investments held by the mutual fund will count towards meeting diversification, making the requirement easier to meet. The Internal Revenue Code (Code) provides look-through treatment for trusts or mutual funds whose beneficial interests are owned only by the accounts of insurance companies (with some exceptions). Through regulation, the tax agencies extended this look-through rule to partnerships but they allowed it to apply to private placement partnerships $^{74}$ whether or not all of the partnership interests were owned by insurance company accounts. ${ }^{75}$ Starting in the late 1990s, taxpayers asserted that this look-through rule for private placement partnerships allowed the development of hedge fund wrappers. The tax agencies responded by correcting the look-through rule and reemphasizing the primacy of the investor control doctrine.

\section{B. The "Investment Annuity"}

In 1963, First Investment Annuity Co. (FIAC) was organized. ${ }^{76}$ The founder envisioned using Congress's 1962 legislation to "create a separate account for each purchaser of a variable annuity and let him control the investments." 77 This proposal was submitted to the Service

12 See infra Part III.E.2.

${ }^{73}$ I.R.C. $\$ 817(\mathrm{~h})(4)$.

74 These are partnerships subject to fewer securities law reporting requirements because interests are marketed only to a limited group of sophisticated investors.

75 Current regulations only allow the look-through rule to apply to partnerships whose beneficial interests are owned by insurance accounts and certain other qualified investors. See infra notes $235-41$ and accompanying text.

${ }^{76}$ Scheibla, supra note 35 , at 24.

${ }^{7}$ Id. 
which reportedly "stud[ied] the plan for two years" and then "gave its approval.," The first "investment annuity" was sold in 1965.79 This product was similar to the variable annuity because its return was tied to the market value of an underlying account. ${ }^{80}$ However, over time, several features were added that made this product significantly more attractive from a tax perspective than the ordinary variable annuity.

The investment annuity allowed policyholders to select and control the underlying account assets. ${ }^{81}$ The policyholders could also designate a manager to control the account assets on their behalf. ${ }^{82}$ The only limitation on the policyholders' discretion with respect to these assets was that they could only select from investments that were on an "approved list." ${ }^{, 83}$ The list for investment annuities included "publicly traded securities, while in other cases the list [was] restricted to Federally insured bank deposit instruments." cases these lists were so extensive that they would have provided almost no restraint on the policyholders' discretion. ${ }^{85}$ The assets

${ }^{78}$ Id.

79 See Vinyard, supra note 34, at 1767-68 (describing the development and features of the investment annuity); Justices Hold Insurance Credit Practices Must Conform to Federal Lending Laws, WALL ST. J., June 3, 1980, at 12.

${ }^{80}$ Inv. Annuity, Inc. v. Blumenthal, 442 F. Supp. 681, 685 (D.D.C. 1977), rev'd, 609 F.2d 1 (D.C. Cir. 1979).

${ }^{81}$ Id; see also Rev. Rul. 77-85, 1977-1 C.B. 12 (describing the policyholder's control over account direction); Steven S. Anreder, Attractive 'Wrapper': The Investment Annuity Has Begun to Catch On, BARRoN's, Nov. 17, 1975, at 3 (describing as "a prime attraction of the investment annuity" that the contract holder retained management over the underlying assets).

${ }^{82}$ FIAC Advertisement, Barron's, Nov. 29, 1971, at 2 (advertising that "the buyer can select his own investment manager: stockbroker, bank, mutual fund, investment advisor").

${ }^{83}$ See Howard Stecker et al., Separate Account Products: A Story of Natural Selection Along the Insurance Product Continuum, TAX NOTES TODAY (Aug. 5, 1998) (LEXIS, FEDTAX lib., TNT file, elec. cit., 98 TNT 150-28) (describing the lists).

${ }^{84}$ Rev. Rul. 77-85, 1977-1 C.B. 12.

${ }^{85}$ Gair Petrie, Eroding the Tax Benefits of Wrap-Around Annuities: An Analysis of Revenue Ruling 81-225, 34 U. FLA. L. REV. 95, 99 n.32 (1981):

Investments approved by the First Investment Annuity Company of America included: securities listed on the New York Stock Exchange; mutual funds; United States and Canadian Government Bonds; certificates of deposit; savings accounts; debt instruments of corporations which would reasonably be expected to be listed on an exchange regulated by the Securities Exchange Commission; commercial paper; term life insurance; and any other asset which met the company's standard for acceptability, which basically required a regular market in the asset. 
underlying the annuity were held not by the insurance company but by a bank custodian or brokerage firm. ${ }^{86}$

Contract holders could make premium payments by transferring financial assets they already owned into the annuity, so long as such assets were on the approved list of underlying annuity investments. ${ }^{87}$ Policyholders were not, however, able to take cash or assets directly out of the custodial account. Instead, they were required to complete a full or partial surrender of the annuity with the insurance company. ${ }^{88}$ The company would direct the custodian to liquidate a portion of the assets and turn the money over to it, and the company would then make the cash payment to the shareholders. ${ }^{89}$ Taxpayers also had the

See also Anreder, supra note 81, at 3 (describing permissible assets).

${ }^{86}$ Inv. Annuity, Inc. v. Blumenthal, 442 F. Supp. 681, 685 n.1 (D.D.C. 1977), rev'd, 609 F.2d 1 (D.C. Cir. 1979); see also Stecker et al., supra note 83 (describing the custodial system for investment annuities).

${ }^{87}$ See Rev. Rul. 77-85, 1977-1 C.B. 12. The transfer of appreciated assets to these accounts would, however, have triggered gain recognition. This may have operated as some deterrent on the movement of previously held portfolio assets into these accounts. See Petrie, supra note 85, at 100-01 (describing gain recognition triggered by transfer of appreciated assets); Anreder, supra note 81, at 20 (same).

As described supra at note 65 , the taxation of net capital gains at the insurance company level seems to have had little effect on the desirability of the investment annuity for individuals. See also Robert Metz, Market Place: Using Annuities as Tax Shelters, N.Y. TImEs, Feb. 5, 1976, at 42 (describing growth of investment annuities in spite of the capital gains tax); cf. Anreder, supra note 81, at 3 (reporting that "some people" contended that the capital gains tax would make the investment annuity less desirable). In the investment annuity context, the companies apparently passed this capital gains tax on directly to the contract holder by debiting the account. See id. (describing how company-level capital gains triggered a reduction in a contract holder's account).

Code section 817(b) was enacted in 1984 and effectively ended taxation at the life insurance company level on the investment returns, including capital gains, generated by the separate accounts of variable contracts. I.R.C $\S 817(\mathrm{~b})$; see Skillman, supra note 1, at 40-41 (explaining this legislation).

88 See Rev. Rul. 77-85, 1977-1 C.B. 12. But see Anreder, supra note 81 , at 20 ("After a stated period of time, most plans allow withdrawals (at times with the aforesaid penalty fee).").

Amounts withdrawn would have been taxed under favorable, investment-first treatment. See Donald C. Alexander, Alexander Challenges IRS Authority to Add Limitations on Policyholder Control of Deferred Variable Annuity Contracts, TAX NoTES TODAY (June 7, 1990) (LEXIS, FEDTAX lib., TNT file, elec. cit., 90 TNT 12023) (explaining the investment-first treatment).

${ }^{89}$ See Rev. Rul. 77-85, 1977-1 C.B. 12. Of course, at each step, the custodian and/or the insurance company would extract a fee. In addition to transaction-specific fees, the custodian collected a monthly fee and the insurance company a yearly fee. See Petrie, supra note 85, at 100 (describing typical fees); Anreder, supra note 81, at 
ability to borrow money from annuities (or otherwise pledge annuities as collateral) without being subject to taxation. ${ }^{90}$

Although investment annuities created significant tax avoidance possibilities, ${ }^{91}$ beginning in 1965 and continuing for just over ten years, the Service issued numerous private letter rulings holding that such custodial accounts qualified as life insurance company accounts. ${ }^{92}$ Thus, although the Service had access to information about the basic contours of the investment annuities, it did not act to limit the product until the product became more widespread. For nearly a decade, only one company - FIAC - offered the investment annuity. ${ }^{93}$ The first policies were group plans designed primarily for public school teachers, ${ }^{94}$ and there was a relatively small likelihood of abuse. ${ }^{95}$ It is therefore not surprising that the Service issued favorable private letter rulings and even one favorable revenue ruling. ${ }^{96}$ In addition, it is doubtful whether FIAC emphasized the tax benefits when requesting the private letters for these group investment annuities. For example, the favorable revenue ruling did not describe the unique features of

20 (describing typical fees); Metz, supra note 87 , at 42 (quoting an observer who described the fees as "the price of admission to the shelter").

${ }^{\circ}$ See supra Part II.A.

${ }^{91}$ Inv. Annuity, Inc. v. Blumenthal, 609 F.2d 1, 3 n.8 (D.C. Cir. 1979) (describing tax benefits of the investment annuity); see also Alexander, supra note 88 (stating that through an investment annuity, "a taxpayer could have converted virtually any currently taxable income stream into a tax-deferred variable annuity"); Anreder, supra note 81 , at 3 (describing tax savings).

${ }_{92}$ See Inv. Annuity, Inc. v. Blumenthal, 442 F. Supp. 681, 685 n.2 (D.D.C. 1977), rev'd, 609 F.2d 1 (D.C. Cir. 1979); A. H. Doggart, Letters to the Editor, 5 TAX NoTES 23, 24 (Feb. 28, 1977) (describing favorable letter rulings); Petrie, supra note 85, at 100 (stating that there were "about seventy favorable letter rulings"); Tax Briefs, Bus. WK., May 9, 1977, at 114 (quoting vice president of First Investment Annuity Co. as saying that the "IRS issued one public ruling and 75 private rulings upholding the idea").

${ }^{93}$ See Metz, supra note 87, at 42 ("Until a year ago, all investors bought their annuities from the pioneer, the First Investment Annuity Company of America, a small Valley Forge, Pa., concern.").

${ }^{94}$ See Calvin H. Johnson, Professor Johnson Replies, Letter to the Editor, 5 TAX Notes 24, 26 (Feb. 29, 1977) (describing investment annuities sold to teachers' qualified pension plans); Treasury Grandfathers Investment Annuities, 5 TAX NOTES 21, 21 (Mar. 14, 1977) (same).

95 See Johnson, supra note 94, at 26 (explaining that the favorable rulings were an error that "at first was a small one").

${ }^{96}$ Rev. Rul. 68-488, 1968-2 C.B. 188; see Treasury Grandfathers Investment Annuities, supra note 94 , at 21 (explaining that this ruling did not address purchaser control over investments). 
the investment annuity. ${ }^{97}$

FIAC was not, however, content to provide retirement services to school teachers and turned to promoting the investment annuities to wealthy individuals $^{98}$ as effective tax-sheltering devices. ${ }^{99}$ Notwithstanding the expanded possibility for tax avoidance, the Service issued favorable private letter rulings for these individual investment annuities. The letter ruling requests submitted by FIAC may have downplayed facts that would have led the Service to recognize the tax avoidance possibilities. A favorable letter ruling issued in 1972, for example, did not mention the lists of approved securities or otherwise emphasize the contract holder's control. ${ }^{100}$ Instead, the ruling stated only " $[\mathrm{t}]$ he contract holder retains the right to direct the Custodian as to investment activity with respect to the investments in the account but cannot receive any payments from the account." ${ }^{101}$ The ruling emphasized that any amounts earned on the contract would be paid only to the insurance company and that the custodian and annuity agreements were "irrevocable." 02 No

97 The ruling specifically addressed a question unrelated to contract holder control: "Whether employer payments under an investment arrangement are contributions to purchase section 403(b) annuity contracts where the employee is entitled to benefits immediately after the initial payment by the employer." Rev. Rul. 68-488, 1968-2 C.B. 188.

${ }_{98}$ The timeframe is not entirely clear, but these individual investment annuities appear to have first been issued in the early 1970s. See I.R.S. Priv. Ltr. Rul. 72-04041250A (Apr. 4, 1972) (stating that FIAC was "preparing to offer to the public an annuity arrangement"); Anreder, supra note 81 , at 3 (explaining that individual investment annuity purchases "quadrupled in 1974, to $\$ 36.2$ million, from 1973 's $\$ 9.4$ million”); FIAC Advertisement, BARRON's, Mar. 9, 1970, at 9 (FIAC advertisement for individual investment annuities).

${ }_{99}$ Advertisements by FIAC that appeared in Barron's are revealing. See, e.g., FIAC Advertisement, BARRON's, Mar. 15, 1971, at 12 ("Expecting a Pension or ProfitSharing Plan distribution? You may also expect a big tax headache."); FIAC Advertisement, BARRON's, May 17, 1971, at 29 (describing the product as "a tax shelter"); FIAC Advertisement, supra note 82, at 2 ("Like all annuities, it offers taxshelter advantages. Alone among annuities, however, it offers certain unique advantages."); see also Johnson, supra note 94, at 26 (describing FIAC as having "used the easement for a little brick road to build its eight-lane interstate").

${ }^{100}$ I.R.S. Priv. Ltr. Rul. 72-04-041250A (Apr. 4, 1972).

101 Id.

${ }^{102}$ Id. After the Internal Revenue Service (Service) took action against investment annuities, insurance representatives did not distinguish between the group and individual policies. For example, the insurance companies reacted by emphasizing that the policies had also been purchased by "public service individuals": "Anthony H. Doggart, president of Investment Annuity, said yesterday that his company at present had about 15,000 such policies outstanding for such public service 
discussion was included about the possibility of surrendering the contract.

Beginning in 1975, other insurance companies began offering versions of the investment annuity. ${ }^{103}$ Starting in late 1975 , a cluster of stories appeared in the financial and popular press dubbing the investment annuity the "wraparound annuity" and describing it as a tax shelter used by wealthier individuals. ${ }^{104}$ In a memorandum submitted in the only reported court case involving investment annuities, ${ }^{105}$ the Service stated that it had decided to begin a "reconsideration of their earlier private letter ruling policy" because of the stories by "tax experts [and] tax financial journalists" who had "fully perceived the tax avoidance capability in investment annuities." 106

The Service warned publicly in October 1976 of its decision to reconsider investment annuities. ${ }^{107}$ In March $1977,{ }^{108}$ the Service

individuals as school teachers in a total of 39 states." Tax Ruling by the I.R.S. Could Affect Future Sales of Investment Annuities, N.Y. Times, Mar. 9, 1977, at D5.

${ }^{103}$ See Metz, supra note 87 , at 42 (describing the growth in investment annuity offerings). By early 1977, eleven companies were offering investment annuities. See A Tax Break Falls, Bus. WK., Mar. 21, 1977, at 44 (describing eleven companies as selling investment annuities worth $\$ 500$ million); Anreder, supra note 81 , at 3 ("FIAC has a big jump on its rivals. But the competitive pace is heating up."); IRS Triggers Investment Annuities Protest, 4 TAX NotEs 15, 15 (Dec. 20, 1976) ("[A]pproximately $\$ 500$ million in investment annuities have been sold by 11 companies."); Tax Men Question Investment Annuities, Bus. WK., Oct. 18, 1976, at 112 ("Since . . last January, insurance companies have written close to $\$ 250$ million worth of investment annuities.").

${ }^{104}$ See Anreder, supra note 81, at 3 (describing the benefits of the investment annuity to individuals "in tax brackets of $30 \%$ and higher"); Metz, supra note 87 , at 42 (describing advantages of investment annuity); The Tax Break In Investment Annuities, Bus. WK., Feb. 9, 1976, at 74 (same).

FIAC, of course, took issue with the descriptions of its products as tax shelters. Doggart, supra note 92, at 23 (describing the investment annuity with the phrase "[s]carcely a tax shelter"). Their own advertisements, however, belie their defense. See supra note 99.

${ }^{105}$ Inv. Annuity, Inc. v. Blumenthal, 442 F. Supp. 681,685 (D.D.C. 1977), rev'd, 609 F.2d 1 (D.C. Cir. 1979), discussed supra at note 91.

${ }^{106}$ Id. at 693 (quoting from a Service memorandum); see Goldberg \& Lemke, supra note 28 , at $443-44$ (describing shift in agency stance on investment annuities); Petrie, supra note 85 , at 100.

${ }^{107}$ Inv. Annuity, Inc., 442 F. Supp. at 685 n.2; see Calvin H. Johnson, Changing the Rules on Investment Annuities: The Problem of Grandfathers and Past Years, 5 TAX NOTES 5, 6 (Jan. 31, 1977) (describing the Oct. 20, 1976 news release); Tax Men Question Investment Annuities, supra note 103, at 112 (discussing the Service's intention "to alter the investment annuity's tax status"); see also IRS Triggers 
issued Revenue Ruling $77-85,{ }^{109}$ which held that the contract holders and not the custodians or insurance companies were the true owners of the assets inside the custodial accounts. ${ }^{110}$ The ruling explained that while the Code did contemplate that policyholders could "bear the investment risk with respect to segregated asset accounts of the insurance company," it did not cover assets over which the policyholders had "direct investment control and [could] exercise other incidents of ownership." 111 The ruling emphasized the "bundle of rights" held by the individual policyholder and pointed to escrow and trust cases in which persons who placed the property in those vehicles were deemed to be the owners of that property. ${ }^{112}$ Thus, the

Investment Annuities Protest, supra note 103, at 15 (describing how the Service's announcement "triggered letters of protest from two members of Congress").

Lobbying efforts on the part of the insurance industry began almost immediately. Investment Annuity Decision Left to Democrats, 5 TAX NOTES 3, 3 (Jan. 31,1977 ) (describing lobbying efforts led by FIAC).

${ }_{108}$ The presidential election between Jimmy Carter and Gerald Ford took place in 1976. Thus, the proposal made to end the favorable treatment for investment annuities was raised by the Ford Treasury and implemented by the Carter Treasury. See Investment Annuity Decision Left to Democrats, supra note 107, at 3 ("The fact that the IRS, in a pro-business Republican administration, was willing to reverse itself ... is taken by some tax experts as evidence the IRS made an obvious mistake when it issued the initial rulings ...."). Agency action taken to constrain wraparound insurance has been consistently bipartisan. See infra note 148 (Carter and Reagan administrations) and Part III.F (current Bush administration).

109 Rev. Rul. 77-85, 1977-1 C.B. 12. Revenue Ruling 77-85 was made prospective only, although the grandfathering of previously established investment annuities was subject to two conditions. First, no further contributions could be made to these accounts after the date of the ruling release, which was March 9, 1977. Id. at 15. Second, the account assets had to be "consistently treated as the property of the insurance company for all purposes under ... the Code." Id. This second restriction would have required contract holders to yield investment control to the insurance companies. See Johnson, supra note 107, at 6-7 (arguing that any Service authority should not allow grandfathering for existing contracts).

${ }^{110}$ See Skillman, supra note 1 , at 40-38 (describing the Service's change in position on investment annuities and the issuance of Revenue Ruling 77-85); A Tax Break Falls, supra note 103, at 44 (same); IRS Ends Deferral Granted Investment Annuity Contracts, WALl ST. J., Mar. 10, 1977, at 3 (same); Tax Briefs, supra note 92, at 114 (same).

The insurance companies reacted by emphasizing that the policies had also been purchased by "public service individuals." See supra note 102.

${ }^{111}$ Rev. Rul. 77-85, 1977-1 C.B. 12, 14 (emphasis in original).

112 Id. at 14,15 . The specific case referenced in the Revenue Ruling was Northern Trust Co. of Chicago v. United States, 193 F.2d 127 (7th Cir. 1951). In Northern Trust, the buyer of stock had the seller deposit the shares in escrow until the full purchase price was paid over time. The buyer of the stock had the right to vote 
ruling is essentially a pure application of constructive ownership principles, ${ }^{113}$ and it is generally considered the first of the "investor control" rulings. ${ }^{14}$

After the issuance of Revenue Ruling 77-85, the Service continued to struggle with its policy on wraparound insurance products. ${ }^{115}$ For example, in August 1977, months after the issuance

the shares. Dividends paid on the stock were paid over to the seller but also reduced the remaining amount owing by the buyer. The court, quoting Justice Frankfurter, explained: "We cannot too often reiterate that taxation is not so much concerned with the refinements of title as it is with actual command over the property taxed - the actual benefit for which the tax is paid." 193 F.2d at 129 (quoting Griffiths v. Commissioner, 308 U.S. 355, 357 (1939)) (internal quotation marks omitted). The Seventh Circuit held that the buyer was the owner of the shares and thus would be taxed on the dividends paid on the shares while they remained in escrow. Id. at 131 .

113 Two of the most well known cases in this area are Corliss v. Bowers, 281 U.S. 376 (1930), and Helvering v. Clifford, 309 U.S. 331 (1940). These cases were both cited in the investor control rulings issued in 2003; see infra Part III.F. See also Internal Revenue Service, Regs Target Use of Annuity Contracts, Life Insurance As Tax Avoidance Vehicles, TAX NOTES TODAy (July 30, 2003) (LEXIS FEDTAX lib., TNT file, elec. cit., 2003 TNT 146-11, n.3) ("These [investor control] rulings apply general concepts of ownership that have developed in case law ...."); Petrie, supra note 85, at 95 n.2 (describing the application of "Clifford's logic" to wraparound annuities). For a discussion of Corliss, see Patricia A. Cain, The Story of Earl: How Echoes (and Metaphors) from the Past Continue to Shape the Assignment of Income Doctrine, in TAX STORIES: AN IN-DEPTH LOOK AT TEN LEAdiNG FEDERAL INCOME TAX CASEs 275, 278 (Paul L. Caron ed., 2003). For a discussion of both Corliss and Clifford, see Joseph M. Dodge ET AL., Federal Income TAX: Doctrine, STRUCTURE, AND POLICY 824-25 (3d ed. 2004).

${ }^{114}$ Cf. David S. Neufeld, The 'Keyport Ruling' and the Investor Control Rule: Might Makes Right?, TAX NOTES TOdAy (Jan. 20, 2003) (LEXIS, FEDTAX lib., TNT file, elec. cit., 2003 TNT 14-51) (describing this ruling as the "false progenitor" of investor control).

${ }^{115}$ This may have resulted from actions taken by insurance companies negatively affected by the ruling. The companies petitioned Congress to overturn it through legislation. See Petrie, supra note 85, at 101-02 (describing the effort to overturn the ruling); Scheibla, supra note 35, at 24.

The Carter administration proposed codification of Revenue Ruling 77-85. Neither side was able to convince Congress to act. See Goldberg \& Lemke, supra note 28 , at $447-48$ (describing failure to get congressional action about the revenue ruling); Vinyard, supra note 34, at 1770 (describing Carter administration proposal).

In addition to pursuing a legislative solution, FIAC and its parent filed a lawsuit in which they sought "a declaratory judgment that Revenue Ruling 77-85 is unlawful, beyond statutory authority, and in violation of the Internal Revenue Code." Inv. Annuity, Inc. v. Blumenthal, 442 F. Supp. 681, 686 (D.D.C. 1977), rev'd, 609 F.2d 1 (D.C. Cir. 1979). The plaintiffs also sought "injunctive relief to restrain the defendants from implementing Revenue Ruling 77-85 ..." Id. The plaintiff prevailed in the district court, which held that it was compelled "to conclude that 
of Revenue Ruling 77-85, the Service issued a favorable letter ruling for an annuity that was identical to the investment annuity except that the insurance company, rather than a custodian, held the accounts. ${ }^{116}$ This letter ruling was hastily revoked ${ }^{117}$ after FIAC brought it forward during the course of litigation over Revenue Ruling 77-85. ${ }^{118}$ The Service, however, continued to issue favorable letter rulings for other

Revenue Ruling 77-85 is erroneous and unreasonable, and therefore unlawful and beyond the Service's statutory authority." Id. at 688 . The case was reversed on appeal on a procedural point.

The district court held that the contract holders needed to retain "total control" before being deemed the owners of the investment annuity assets. Id. at 690-91. The court specifically described the Clifford case as requiring such an approach. See supra note 113. The court explained that the "investment annuity policyholders have manifestly effected a 'substantial change' in their economic positions. While they retain investment control over the account assets, they by no means retain control over such assets 'in all essential respects' as before the investment." Inv. Annuity, Inc., 442 F. Supp. at 690 . The court then went on to identify the ways in which policyholders' rights were impaired: “[P]olicyholders are unable to receive the account assets back in kind ... and they may not receive any amount directly from the account." Id. These points were also made in the early, favorable private letter rulings. The court noted that if the policyholder surrendered the contract, "he would have to pay full taxes at that time for any appreciation in the account assets ..." Id. at 691. That this tax deferral was the point of the investment annuity did not influence the court. See Petrie, supra note 85 , at 108-10 (discussing the ways in which the court's logic was "patently incorrect"). The court did, however, emphasize that for just over ten years the Service had issued favorable rulings to investment annuity companies: "While such a reconsideration of policy may indeed be desirable, Congress, not the Internal Revenue Service, is the appropriate body to consider such substantive changes in the tax laws." Inv. Annuity, Inc., 442 F. Supp. at 693.

116 I.R.S. Priv. Ltr. Rul. 77-47-111 (Aug. 29, 1977). For example, the ruling describes in detail an "acceptable assets list," the ability of contract holders to make in-kind contributions to the account, and includes a full paragraph about the contract holder's ability to direct investments inside the annuity and the shifting of investment risk caused by this arrangement.

117 I.R.S. Priv. Ltr. Rul. 77-47-111 was revoked by I.R.S. Priv. Ltr. Rul. 78-05-020 (Sept. 13, 1977). The revocation letter stated that the revocation was required because "on our subsequent analysis of the application of Rev. Rul. 77-85 ... [that letter] was in error." The letter even contained an apology: "We regret the inconvenience our mistake has caused you." I.R.S. Priv. Ltr. Rul. 78-05-020 (Sept. 13, 1977).

118 Inv. Annuity, Inc., 442 F. Supp. at 686 . The ruling was issued to one of the plaintiff's competitors. Id. The ruling was raised in the Investment Annuity case described supra note 115. The district court stated that the private ruling "raised grave questions about the propriety of Revenue Ruling 77-85." Id. at 686 (internal quotation marks omitted); see also Scheibla, supra note 35, at 24, 26 (describing the issuance of the ruling to FIAC's competitor and the reaction of the district court). 
annuities that were similar in structure to the investment annuity. ${ }^{119}$

The limitations of the investor control doctrine were not evident immediately following issuance of the investment annuity revenue ruling. The insurance companies selling the investment annuity did not assert that the Service's ruling was meaningless; indeed, the revenue ruling ended the investment annuity and put its sellers out of business. ${ }^{120}$ Even in the investment annuity, however, one can see the obstacle that would face the tax agencies in future wraparound insurance iterations. Because the investment annuity allowed a clear view of an identical investment existing both inside and outside the contract, that vehicle dramatically revealed the inconsistency between the tax treatment of returns inside and outside variable contracts. That same inconsistency is present in even the most plain-vanilla variable contracts sold today; it is just less obvious. ${ }^{121}$ This inconsistency, protected by legislation, perpetuates the wraparound insurance shelter.

\section{Savers' Annuities}

From 1977 to 1979 , the Service issued favorable letter rulings ${ }^{122}$

119 Petrie, supra note 85, at 103 (describing marketing of products designed "to produce the same effects as the investment annuity"); see Goldberg \& Lemke, supra note 28 , at 444 (describing the popularity of these annuity types during the late 1970s); Vinyard, supra note 34, at 1768 (describing these types of annuities as having been "developed in the latter part of the 1970 s to avoid problems encountered by investment annuities with the IRS").

${ }^{120}$ The primary seller of the investment annuity, First Investment Annuity Inc., was unable to recover from the effects of Revenue Ruling 77-85. See Investment Annuity Says Holder Clear Plan for Firm's Liquidation, WALL ST. J., Mar. 31, 1978, at 28 (describing liquidation plans of Investment Annuity, Inc.); IRS Ends Deferral Granted Investment Annuity Contracts, WALL ST. J., Mar. 10, 1977, at 3 (describing suspension of investment annuity sales following issuance of Rev. Rul. 77-85).

${ }^{121}$ Indeed, the financial press today describes even the blandest of variable contracts as mutual funds wrapped in insurance. See, e.g., Jonathan Clements, Defending a Much-Maligned Investment: When Variable Annuities Make Sense, WALL ST. J., Oct. 20, 2004, at D1 ("Variable annuities which allow you to buy mutual funds inside a tax-deferred wrapper ...."); Ian McDonald, Mutual-Fund Scrutiny Spreads to Annuities - Regulators See the Fingerprints of Market Timers in the Accounts Often Held by Cautious Investors, WALL ST. J., Nov. 7, 2003, at C1 ("Variable annuities are essentially tax-deferred mutual-fund accounts with an insurance wrapper.").

122 I.R.S. Priv. Ltr. Rul. 77-48-012 (Aug. 30, 1977); I.R.S. Priv. Ltr. Rul. 78-49-013 (Sept. 6, 1978); I.R.S. Priv. Ltr. Rul. 79-03-101 (Oct. 23, 1978); I.R.S. Priv. Ltr. Rul. 79-06-058 (Nov. 9, 1978); I.R.S. Priv. Ltr. Rul. 79-51-114 (Sept. 21, 1979); see Vinyard, supra note 34 , at $1770 \&$ n. 17 (describing some of these letter rulings). 
for "savers' annuities," 123 which were structurally similar to investment annuities. ${ }^{124}$ Under the savers' annuity, a savings and loan association (S\&L) contracted with an insurance company to act as the "group contract-holder under an annuity plan." company then marketed the savers' annuity to the existing depositors at the S\&L. These depositors would transfer cash, an existing passbook account, or a $\mathrm{CD}$ to the insurance company in exchange for the annuity contract. ${ }^{126}$ The insurance company transferred these premium funds (minus a fee for itself) to the $S \& L$, which invested them in a federally insured $\mathrm{CD}^{127}$ with a term designated by the contract holder. ${ }^{128}$ As with the investment annuity, the contract holder did "not have direct access to the interest earned on the deposit in the S\&L except as the terms of the Annuity Plan allow him payments of benefits, loans on the cash value of the policy, or surrender of the policy for its cash value less a cash surrender charge." ${ }^{29}$ Some contract plans allowed contract holders to withdraw as much as $4 \%$ of principal per year without a penalty charge. ${ }^{130}$

${ }^{123}$ See Calhoun, supra note 23, at 774-75 (describing these annuities).

${ }^{124}$ See Vinyard, supra note 34, at 1765-66 (describing the savers' annuities and the favorable Service letter rulings).

${ }^{125}$ Rev. Rul. 80-274, 1980-2 C.B. 27.

${ }^{126}$ See id.; I.R.S. Priv. Ltr. Rul. 77-48-012 (Aug. 30, 1977); I.R.S. Priv. Ltr. Rul. 78-49-013 (Sept. 6, 1978); I.R.S. Priv. Ltr. Rul. 79-03-101 (Oct. 23, 1978); I.R.S. Priv. Ltr. Rul. 79-06-058 (Nov. 9, 1978).

127 See Calhoun, supra note 23, at 776 ("Many analysts believed that the key factor in Revenue Ruling 80-274 was each policyholder's entitlement to $\$ 100,000$ of FSLIC insurance."); Skillman, supra note 1, at 40-38 (describing the savers' annuity); Donald Moffitt, Being Both a Borrower and a Lender Can Pay; New Plan Offers Tax Deferral on Bank Savings, WALL ST. J., Oct. 29, 1979, at 48 (describing federal insurance for savers' annuities).

128 Rev. Rul. 81-225, 1981-2 C.B. 144, discussed infra Part III.D, highlighted this fact: "Similarly, Rev. Rul. 80-274 ... holds that the purchaser of an annuity contract, by means of which the purchaser selected and controlled specified certificates of deposit ... is considered the owner of the certificates ...." (emphasis added).

When a particular $C D$ expired, the proceeds would be reinvested in a $C D$ of the same duration as the original. If the term on the $C D$ extended beyond the start date of the annuity payments, then the funds were invested in a passbook savings account instead. Rev. Rul. 80-274, 1980-2 C.B. 27.

${ }^{129}$ See I.R.S. Priv. Ltr. Rul. 77-48-012 (Aug. 30, 1977).

130 See Moffitt, supra note 127, at 48 (describing such a provision and stating, "[o]therwise, withdrawals are subject to charges that start at $7 \%$ in the first year and fall by one percentage point a year to the eighth year...."). Loans taken against annuity cash value were not taxed at this point in time. See supra Part II.A. 
Savers' annuities had a limited but significant following ${ }^{131}-$ a following perhaps due more to marketing efforts than to the actual value of these products as investments. The yield on the plans, after taking into account tax on withdrawals, was somewhat less than that on tax-exempt bonds. ${ }^{132}$ The plans were available for premium payments as low as $\$ 1,000$ and were within reach of less affluent investors. ${ }^{133}$ When the Service moved against these plans, as described below, insurance company representatives speculated that the Service was attempting to cut off the tax benefits before they became too widely available. ${ }^{134}$

In December of 1979, the Service took a first tentative step in reconsidering its policy on savers' annuities when it withdrew prior favorable private rulings. ${ }^{135}$ The reason given by the Service for the withdrawals was based on a technical problem with the original letter ruling requests. ${ }^{136}$ The insurance companies were quickly able to

${ }^{131}$ Jill Bettner, IRS Draws a Bead on 'Wraparound Annuities,' Threatens Popular Tax-Deferral Savings Plans, WALL ST. J., Oct. 6, 1980, at 56 (reporting on estimates of the involvement of at least $500 \mathrm{~S} \& \mathrm{Ls}$ ); see also Moffitt, supra note 127 , at 48 (describing one bank that received nearly $\$ 1$ million in investments in one year).

${ }^{132}$ See Moffitt, supra note 127 , at 48 (describing plan offering yields between 7 percent and 8 percent).

133 See Bettner, supra note 131, at 56 ("Some saver annuities have minimums of as little as $\$ 1,000$. The minimum initial deposit for mutual-fund annuities ranges from $\$ 1,500$ to $\$ 3,000$."); Moffitt, supra note 127 , at 48 (describing the availability of a " $\$ 1,000$ certificate with a net annual yield of $7.17 \%$ ").

${ }^{134}$ Bettner, supra note 131, at 56 (quoting one representative who said, "[w]ith relatively small companies... can you imagine what would happen if the big boys got in? ... The IRS wasn't getting a piece of the action.") (internal quotation marks omitted).

135 I.R.S. Priv. Ltr. Rul. 80-08-185 (Dec. 3, 1979) (withdrawing I.R.S. Priv. Ltr. Rul. 79-06-058); I.R.S. Priv. Ltr. Rul. 80-08-210 (Dec. 3, 1979) (withdrawing I.R.S. Priv. Ltr. Rul. 79-03-101); I.R.S. Priv. Ltr. Rul. 80-08-215 (Dec. 3, 1979) (withdrawing I.R.S. Priv. Ltr. Rul. 78-49-013); I.R.S. Priv. Ltr. Rul. 80-09-042 (Dec. 4, 1979) (withdrawing I.R.S. Priv. Ltr. Rul. 77-48-012).

${ }^{136}$ The insurance companies had represented in their ruling requests that they were the titled owners of the underlying investment assets. See I.R.S. Priv. Ltr. Rul. 77-48-012 (Aug. 30, 1977) (stating that the insurance company would hold legal title to the segregated asset accounts). However, the passbook for each account stated "[t]he insurance company holds this account as agent for annuitant..." Id. (emphasis added). The Service's withdrawals were based on a revenue procedure providing that the Service would not rule on tax ownership issues unless the person making the request was the formal owner. Because the agency language in the passbooks was inconsistent with formal ownership of the underlying annuity investments being with the insurance companies, the Service stated it was required to withdraw the rulings. See I.R.S. Priv. Ltr. Rul. 80-08-215 (Dec. 3, 1979); I.R.S. Priv. 
resolve the technical concern. For example, one insurance company ${ }^{137}$ submitted new factual information on December $14,1979,{ }^{138}$ and on January 15, 1980, the Service issued a new private ruling holding that the insurance company and not the annuitant would be treated as the owner of the underlying CDs. ${ }^{139}$ Just a few months later, however, the Service took a public position against the savers' annuity by issuing Revenue Ruling $80-274,{ }^{140}$ the second of the "investor control" rulings. ${ }^{141}$

Ltr. Rul. 80-08-185 (Dec. 3, 1979); I.R.S. Priv. Ltr. Rul. 80-08-210 (Dec. 3, 1979);

I.R.S. Priv. Ltr. Rul. 80-09-042 (Dec. 4, 1979).

${ }^{137}$ The prior rulings issued to the taxpayer were I.R.S. Priv. Ltr. Rul. 77-48-012 (Aug. 30, 1977) and I.R.S. Priv. Ltr. Rul. 80-09-042 (Dec. 4, 1979).

${ }^{138}$ The company stipulated, " $[t]$ he taxpayer will have all the incidents of ownership of the deposits, and the deposits will be held in the taxpayer's own name, and not as an agent for the annuitant." I.R.S. Priv. Ltr. Rul. 80-15-065 (Jan. 15, 1980); see also I.R.S. Priv. Ltr. Rul. 80-24-092 (Mar. 24, 1980) (representing that the "deposits will be segregated accounts for which the insurance company will hold the title and passbooks"); I.R.S. Priv. Ltr. Rul. 80-11-046 (Dec. 19, 1979) (representing that "[t]he Company will hold the passbooks or other indications of ownership in its own name").

139 I.R.S. Priv. Ltr. Rul. 80-15-065 (Jan. 15, 1980).

140 Rev. Rul. 80-274, 1980-2 C.B. 27; see Calhoun, supra note 23, at 776 (describing Revenue Ruling 80-274); see also Skillman, supra note 1, at 40-38 (same); Scheibla, supra note 35, at 26 (same).

Revenue Ruling 80-274 "did not provide for an automatic grandfathering of existing contracts.... Rather, companies that previously had received favorable private rulings on their savers' annuities were granted section $7805(\mathrm{~b})$ relief only on a case-by-case basis." Calhoun, supra note 23 , at 775 . Such relief was granted to several of the taxpayers receiving such favorable letter rulings. I.R.S. Priv. Ltr. Rul. 81-08-113 (Nov. 28, 1980) (providing retroactive relief to recipient of I.R.S. Priv. Ltr. Ruls. 78-49-013 and 80-08-215); I.R.S. Priv. Ltr. Rul. 81-08-128 (Nov. 28, 1980) (providing relief to recipient of I.R.S. Priv. Ltr. Ruls. 77-48-012 and 80-09-042); I.R.S. Priv. Ltr. Rul. 81-08-137 (Nov. 28, 1980) (providing relief to recipient of I.R.S. Priv. Ltr. Ruls. 79-06-058 and 80-08-815).

${ }^{141}$ Some insurance companies tried to continue on with the savers' annuity by making slight adjustments designed to circumvent the direct terms of Revenue Ruling 80-274. I.R.S. Priv. Ltr. Rul. 81-32-118 (May 18, 1981). For example, one insurance company "reserve[d] the right to require the substitution of investment instruments held in the Contract owner's individual account." Id. The company would exercise this right "when in its opinion an investment instrument [was] no longer appropriate for the purposes of the Contract or for its administrative procedures." Id. The Service did not waver again as to its approach to this savers' annuity structure:

Although the Contract owner has not chosen the term of the investment instruments which must be purchased for the life of his contract, as he does in Rev. Rul. 80-274, the Contract owner has knowledge of and does consent 
This ruling held that the contract holders should be deemed to own directly the underlying CDs wrapped in the savers' annuities. The ruling explained that "the policyholder's position is substantially identical to what the policyholder's position would have been had the investment been directly maintained or established with the savings and loan association.... [The life insurance company] is little more than a conduit between the policyholder and the savings and loan association." ${ }^{142}$ The ruling cited only Revenue Ruling 77-85 in support of its conclusion, ${ }^{143}$ yet compared to the holder of an investment annuity, the savers' annuity contract holder had little choice as to the type of investments and only received a fixed rate of return tied to a low-risk instrument. ${ }^{144}$ Indeed, the underlying CDs were even federally insured. The savers' annuity was similar to the investment annuity only in that the policyholders and insurance companies made use of third-party custodial arrangements and the underlying investments were CDs available outside the savers' annuity. Thus, Revenue Ruling 80-274's emphasis on the contract holder's position being "substantially identical" to that of an ordinary S\&L presaged the bright-line prohibition against publicly available investments,

to the Company's investment of his funds in whatever instrument has the highest yield at the time funds are available for reinvestment.... The Contract owner is not in a substantially different position from the position he or she would be in had he or she invested a sum of money in a financial institution using the Company as an investment advisor.

Id. For similar negative rulings on annuities similar to savers' annuities, see I.R.S. Priv. Ltr. Rul. 81-32-104 (May 15, 1981); I.R.S. Priv. Ltr. Rul. 81-46-066 (Aug. 21, 1981); I.R.S. Priv. Ltr. Rul. 81-46-067 (Aug. 21, 1981); I.R.S. Priv. Ltr. Rul. 81-47-197 (Aug. 31, 1981).

As occurred following the issuance of Revenue Ruling 77-85, legislation was proposed to overturn Revenue Ruling 80-274. This was opposed by the Treasury on the basis "that the legislative history of the 1959 and 1962 insurance company tax laws indicated that Congress contemplated tax-deferred treatment only for variable annuity contracts that involved a commingled investment fund managed by the life insurance company ... and that wrap-around annuities did not fit that description." Goldberg \& Lemke, supra note 27, at 449-50 (internal quotation marks omitted); see also Jill Bettner, Wraparound Annuities Could Be Hurt by Expected IRS Ruling on Ownership, WALL ST. J., Sept. 17, 1981, at 4 (describing lobbying efforts by insurance industry); Scheibla, supra note 35 , at 11 (describing bills introduced to reverse the rulings on investment annuities and savers' annuities).

${ }_{142}$ Rev. Rul. 80-274, 1980-2 C.B. 27.

${ }^{143}$ See Scheibla, supra note 35 , at 26 (arguing that the "IRS failed to provide a legal basis for its action").

144 Calhoun, supra note 23, at 775-76. 
which was adopted in $1981 .^{145}$

\section{Mutual Fund Annuities}

Mutual fund annuities developed contemporaneously with savers' annuities. $^{146}$ Their structure was similar except that the underlying account investments were publicly available mutual funds instead of CDs. Like savers' annuities, mutual fund annuities were also affordable for less affluent taxpayers. ${ }^{147}$ After the issuance of Revenue Ruling 80-274, insurance companies continued marketing annuities wrapped around mutual funds, ${ }^{148}$ even though the Treasury

${ }^{145}$ See Petrie, supra note 85, at 104 (stating that Revenue Ruling 80-274 "stand[s] for the proposition that annuity treatment will not be accorded to transactions which are designed primarily to shield investments from current income taxation"); see also Alexander, supra note 88 (discussing "substantially identical" requirement).

${ }^{146}$ See William G. Flanagan, Creative Brokers Make Annuities a New Means of Using Your Mutual Fund as Tax Shelter, WALL ST. J., July 14, 1980, at 34 (praising the "imagination" of "the peddlers of mutual funds," who with the "aid of the insurance industry," were "pushing a product that gives investors tax-deferred dividends on their mutual fund investments"); Thomas C. Hayes, Your Money; Annuity Funds and Taxes, N.Y. TIMES, Aug. 22, 1981, at 30 (stating that the first annuity of this type "was introduced ... in February 1979"); Scheibla, supra note 35, at 11 (stating that mutual fund annuities "were launched three years ago").

Mutual fund annuities may have been introduced less as a tax ploy and more as a way for mutual funds to stay competitive with insurance. See Thomas, supra note 43, at 17-18 (describing intention of some mutual fund companies of going into field of variable annuities).

${ }^{147}$ Jill Bettner, New IRS Probe Into 'Wraparound Annuities' Isn't Likely to Stall the Tax-Deferral Plans, WALL ST. J., Sept. 21, 1981, at 56 ("Minimum initial deposits are small, ranging from $\$ 1,500$ to $\$ 3,000 . ")$.

${ }^{148}$ See Bettner, supra note 141, at 4 ("Well over half a billion dollars' worth of the annuities have been sold since the plans became available in 1979 ...."); Thomas C. Hayes, Annuity Tax Rule Changed, N.Y. TIMEs, Sept. 26, 1981, at 36 ("It was the lure of deferring taxes... that, in part, attracted more than $\$ 1$ billion into the socalled wraparound annuities in the last three years."); Hayes, supra note 146, at 30 (" $[\mathrm{M}]$ ore than $\$ 1$ billion has flowed into the five biggest funds since ... February 1979.").

Uncertainty over the outcome of the 1980 presidential election (Carter-Reagan) may also have contributed to the continued sales. See Bettner, supra note 131, at 56 ("[A] Treasury Department spokesman ... adds ... that with the November election just around the corner: 'It doesn't make sense to create another firestorm right now' [by issuing another ruling]."). The Reagan administration, however, continued the Carter administration's policy towards wrap-around insurance. Scheibla, supra note 35 , at 11 (describing issuer expectation that Reagan administration "would reverse, or at least call a halt to, the attack on annuities"). 
broadly hinted that the savers' annuity ruling would be extended, ${ }^{149}$ press articles speculated about the imminent demise of mutual fund annuities, ${ }^{150}$ and the SEC required the issuers of mutual fund annuities to disclose the possibility of an adverse Service ruling. ${ }^{151}$

That adverse ruling, Revenue Ruling $81-225$, was issued in a news release dated September $25,1981 .^{152}$ This ruling described several factual situations in which the contract holder would be deemed to be the owner of the underlying contract investments. For example, in the

149 See Vinyard, supra note 34, at 1770 (describing statement by Service Commissioner on ease of expanding the ruling to cover mutual fund annuities); Bettner, supra note 131 , at 56 (describing Treasury statement that the Service was considering extending ruling to mutual fund annuities).

${ }^{150}$ See Goldberg \& Lemke, supra note 28, at 434 (describing financial press reports that "presaged the Service's intentions in this area"); Bettner, supra note 131, at 56 (discussing "the potential for an IRS attack on annuities wrapped around mutual funds").

Business Week initially reported that Revenue Ruling 80-274 extended to mutual fund annuities on its face, Tax Briefs, Bus. WK., Nov. 24, 1980, at 83, but about six weeks later a retraction was issued in connection with a "Readers Report" submitted by a vice president of a financial services corporation. Arnold D. Scott, Readers Report, BUs. WK., Jan. 12, 1981, at 7 (stating that his company was "happy to say that the coup de grâce has not been administered" to mutual fund annuities by the new ruling). This report was accompanied by an editor's note: "Business Week erred in extending the rationale of Revenue Ruling 80-274 to include mutual fund wraparound annuities." Id.

151 See Goldberg \& Lemke, supra note 28, at 449 (describing SEC requirement of disclosing risk of an adverse tax ruling on mutual fund annuities); Vinyard, supra note 34, at 1770 (same); Scheibla, supra note 35, at 11 (describing advertisement including "small print" disclosure about Rev. Rul. 80-274).

${ }^{152}$ Rev. Rul. 81-225, 1981-2 C.B. 12 n.1; see Calhoun, supra note 23, at 777 (describing press release).

Revenue Ruling 81-225 was originally made retroactive to January 1, 1981. Rev. Rul. 81-225, 1981-2 C.B. 12. There was a limited exception for certain qualified group plans. See Calhoun, supra note 23, at 777 (describing the retroactivity provisions of Rev. Rul. 81-225). The investor control doctrine was determined not to apply to these qualified plans in Rev. Proc. 99-44, 1999-2 C.B. 598.

Congress was petitioned to overturn the retroactivity of the ruling. See Clyde H. Farnsworth, Washington Watch: Reliability of U.S. Data, N.Y. TIMES, Nov. 30, 1981, at D2 (describing the industry efforts against retroactivity); Bill Frenzel, Frenzel on 'Wrap-around' Annuities, 14 TAX NOTES 40, 40 (Jan. 4, 1982) (statement by Ways and Means Committee Member calling retroactivity "unconscionable"). The Service responded to the "problems encountered by issuers of wraparound annuities attempting to comply" by affording an additional year's relief for "capital gains dividends and unrealized appreciation." IRS News: Relief Issued for Wraparound Annuity Reporting, 14 TAX NOTES 440, 440 (Feb. 15, 1982); see Calhoun, supra note 23 , at 778 (describing the announcement for some relief from retroactivity). 
first situation, contract premiums could be allocated solely to a publicly available mutual fund. Taxpayers who already owned shares in the mutual fund were allowed to exchange their shares for a variable annuity contract tied to the same mutual fund "without payment of any fee, sales charge or transfer charge." 153 The Service held that the contract holder was the tax owner of this mutual fund ${ }^{154}$ because the contract holder exercised "investment control over the mutual fund shares and possesse[d] sufficient other incidents of ownership to be considered the owner of the mutual fund shares for federal income tax purposes." ${ }^{155}$ The ruling reasoned that the contract holder's position was "substantially identical to what his or her position would have been had the mutual fund shares been purchased directly (or indirectly ...).,"156

${ }^{153}$ Rev. Rul. 81-225, 1981-2 C.B. 12.

154 The Service held that the contract holder was the deemed owner of the underlying contract assets in three other situations. Id. Situation Three was identical to Situation One except that the policyholders were able to allocate premiums to five different publicly available mutual funds instead of to just one. Id. In both Situations One and Three, the mutual funds were managed by a firm unaffiliated with the insurance company. Id. In Situation Two, otherwise identical to Situation One, the insurance company (or one of its affiliates) managed the publicly available mutual fund. Id. Situation Four was identical to Situation Two except that the shares in the mutual fund were available only through the purchase of an annuity contract or by participation in an investment plan account, which was an account created by insurance companies in which customers could invest without the purchase of a variable insurance product. $I d$.

An "investment plan account" was a financial security program set up by a life insurance company for customers who wanted to "obtain advantages commonly associated with mutual funds and retain benefits of the life insurance company's investment management skills." Rev. Rul. 70-525, 1970-2 C.B. 144. The fact that this type of "public" ownership would cause a contract to fail the investor control test is somewhat startling since the investment plan accounts were accounts wholly under the control of the insurance companies, and according to Revenue Ruling 70-525, the investment plan account constituted a "segregated asset account under the insurance laws or regulations of the state." Id. However, since purchase of shares in these accounts was available without purchase of a variable contract, this revenue ruling foreclosed the ability of insurance companies to get around the prohibition on public ownership by simply becoming the issuers of mutual fund interests themselves.

155 Rev. Rul. 81-225, 1981-2 C.B. 12.

156 After revisions to the Code were enacted in the early 1980 s, described infra Part III.E, insurance companies argued that the policyholders' position could no longer be "substantially identical to what it would have been had the mutual fund shares been purchased directly by the policyholders" because the Code restricted the policyholders in several new ways. Rev. Rul. 82-54, 1982-1 C.B. 11; see also infra notes 212-24 and accompanying text (discussing I.R.S. Priv. Ltr. Rul. 2002-44-001 (May 2, 2002)). 
The ruling gave only one example of a situation in which the contract holder would not be deemed the owner of the underlying contract assets. In that example, the facts were the same as those in the first situation except that the mutual fund was available for purchase only through an annuity contract. ${ }^{157}$ About this situation, the ruling stated:

[T] he shares of XY Fund, [the mutual fund], are not separate investments assets; XY Fund is nothing more than the alter ego of IC, [the insurance company].... This situation is equivalent for federal income tax purposes to the direct purchase by IC of the underlying portfolio of assets of XY Fund. IC possesses sufficient incidents of ownership to be considered the owner of these underlying assets for federal income tax purposes. ${ }^{158}$

These statements created the bright-line prohibition on the allocation of premiums or cash value directly to investments also available for purchase outside of the variable insurance. ${ }^{159}$

Revenue Ruling 81-225 was amplified a short time later in

157 There was one difference: in Situation Five, the mutual fund was managed by the insurance company (or one of its affiliates). Rev. Rul. 81-225, 1981-2 C.B. 12. Following the issuance of this ruling, there was also speculation that the ruling created a prohibition against hiring outside managers. Hayes, supra note 148, at 36 (reporting on speculation that mutual funds might be able to stay in the annuity business by starting restricted funds "and having the insurance company that was their partner be the advisor"). The use of outside investment advisers is now clearly permissible under the Code. I.R.C. $\$ 817(\mathrm{~h})(5)$.

158 Rev. Rul. 81-225, 1981-2 C.B. 12.

159 See Alexander, supra note 88 ("Under Rev. Rul. 81-225, then, 'public availability' is the key determinant of whether the policyholder possesses sufficient incidents of ownership to be considered the owner of the underlying investments for tax purposes."); Calhoun, supra note 23, at 777 (describing "implicit rationale" of bright-line rule as being "based on the theory that since the policyholder could acquire the [publicly available] mutual fund shares directly ... the indirect acquisition of shares through a variable annuity should not allow the policyholder to escape from taxation on this income and gain"); Goldberg \& Lemke, supra note 28, at 445 (describing Rev. Rul. 81-225 as providing that "[t]he contractowner [sic] was deemed to have investment control if the fund's shares were available for purchase ... by members of the general public"); Petrie, supra note 85 , at 704 ("The only situation expressly escaping the Service's attack involved a single mutual fund managed by the insurance company that was not available to the general public."); Stecker et al., supra note 83 ("[I]nsurance companies had ... to conform to the Service's position on investor control by replacing publicly available mutual funds as investment options with mutual funds available only to other separate accounts."). 
Revenue Ruling 82-54, which held that an insurance company could allow policyholders to choose between three different funds, so long as these funds were not available for purchase by the public. ${ }^{160}$ Each of the three mutual funds had a different general investment strategy: one invested in common stocks, another in bonds, and a third in money market investments. The ruling held that "the ability to choose among broad, general investment strategies such as stocks, bonds or money market instruments ... does not constitute sufficient control over individual investment decisions so as to cause ownership of the private mutual fund shares to be attributable to the policyholders. ${ }^{, 161}$ This ruling thus solidified the bright-line test under which policyholders would be taxed as owners if they could allocate premium to an investment that was publicly available.

Revenue Ruling 82-54 may provide some content to the general, substance-over-form investor control test. In particular, the tax agencies have discussed issuing rulings regarding the number of available underlying funds. ${ }^{162}$ The concern is that the tax-preferred investment not appear too similar to a taxable investment. That is, the variable contract should not be merely a conduit (which could arise if there were too few fund choices or if the investment strategy was too narrow) and the investors should not have the same range of investment choices inside the contract as they would outside the contract (which could arise $\mathrm{i}_{\llcorner}^{\mathrm{c}}$ there were too many fund choices). ${ }^{163}$ Revenue Ruling 82-54 could be viewed as providing that such

${ }^{160}$ Rev. Rul. 82-54, 1982-1 C.B. 11. The Service also issued Rev. Rul. 82-55, 1982-1 C.B. 12, which addressed whether a mutual fund could "be closed to further purchase by the public and thus be treated ... as owned by the insurance company" and the "effect of post-1980 withdrawals and dividend reinvestment."

${ }^{161}$ Rev. Rul. 82-54, 1982-1 C.B. 11.

162 Alexander, supra note 88 (describing Service's suggestions for "additional restrictions on policyholder control" as likely "focus[ing] on the number of investment choices available to the policyholder and on the frequency with which the policyholder could change his or her choices").

${ }^{163}$ See Thompson, supra note 20, at 508-20 (discussing problems related to number of underlying investments). Other tax-advantaged retirement vehicles, including IRAs and $401(\mathrm{k}) \mathrm{s}$, also provide a number of different investment options, and many nonqualifed deferred compensation arrangements offer a broad array of choices. See id. at 525 n.279. Yet, investor control has not been raised in either of these areas. Id. The Senate recently proposed limits on investment choice in nonqualifed deferred compensation, but this proposal was not enacted. See SenatePassed Version of S. 1637, The Jumpstart Our Business Strength Act, TAX NOTES TODAY (May 20, 2004) (LEXIS, FEDTAX lib., TNT file, elec. cit., 2004 TNT 98-9).

The facts in a recent ruling similar to Revenue Ruling 82-54 allowed for up to twenty fund choices. See infra note 234. 
concerns are alleviated if contract holders are permitted to allocate premiums only to broad investment strategy funds. The problem, however, was that it provided little guidance as to what constituted a broad investment strategy and no guidance on whether the number of funds in the ruling - three - was important to the holding.

The bright-line rule created in Revenue Ruling 81-225 drew criticism from the insurance industry. ${ }^{164}$ Yet, in the week before the

${ }^{164}$ Revenue Ruling 81-225 was also the subject of litigation brought by the Christoffersens, who had paid $\$ 50,000$ for a Pacific Variable Annuity Contract from Pacific Fidelity Life Insurance Company. Christoffersen v. United States, 749 F.2d 513, 514 (8th Cir. 1984). Arthur Christoffersen was an official of the parent of Pacific Fidelity. See Scott R. Schmedel, A Special Summary and Forecast of Federal and State Tax Developments, WALl ST. J., Feb. 22, 1984, at 14. This contract gave the Christoffersens the "right" to purchase an annuity in the year 2021. Christoffersen, 749 F.2d at 514. In the meantime, the $\$ 50,000$ was invested "at plaintiffs' direction, in the Fidelity Daily Income Trust." Id. There was no obligation to ever actually purchase an annuity contract. In addition, the Christoffersens could select "which of the mutual funds offered by Pacific Fidelity to invest in and [could] change to another fund at any time." Id. at 515. The investors could also "withdraw any or all of his investment upon seven days notice." Id.

The Christoffersens paid tax on the income generated by this trust then filed a claim for refund in federal district court. The district court summarily held in favor of the Christoffersens. The district court wrote only: "The contract is an annuity... qualifying for deferred taxation under 26 U.S.C. \& 72." Christoffersen v. United States, 578 F. Supp. 398, 399 (N.D. Iowa) (citing Inv. Annuity, Inc. v. Blumenthal, 422 F. Supp. 681 , 689 (D.D.C. 1977)), rev'd, Christoffersen v. United States, 749 F.2d 513 (1984). The district court's opinion was viewed as a victory by the insurance industry. See Schmedel, supra, at 14 (describing reactions).

The Eighth Circuit reversed the district court, explaining, "[t]he only difference between Pacific Fidelity's arrangement and that of a traditional brokerage firm is the fact that the investor is limited to withdrawing cash." Christoffersen, 749 F.2d at 515. The court, quoting the Supreme Court, explained: "We cannot too often reiterate that taxation is not so much concerned with the refinements of title as it is with actual command over the property taxed - the actual benefit for which the tax is paid." Id. (internal quotation marks omitted). Of the investor control revenue rulings, the court cited only to Revenue Ruling 81-225 and mistakenly viewed it as dealing with the doctrine of constructive receipt rather than tax ownership through control: "Under the long recognized doctrine of constructive receipt, the income generated by the account assets should be taxed to the plaintiffs in the year earned, not at some later time when the Christoffersens choose to receive it. This is the essence of Rev. Rul. 81-225, which we find persuasive." Id. at 516. The court did not focus at all on the unique aspect of the revenue ruling: whether the public availability of underlying contract assets should be sufficient to trigger constructive ownership. Thus, Christoffersen cannot be read as an endorsement of that particular aspect of the investor control doctrine. See Skillman, supra note 1, at 40-39 n.91 (describing Christoffersen). 
ruling was issued, one insurance insider boasted that after the ruling was released, "[e]verybody will be back in business within 48 hours.... There's nothing short of changing the law we can't get around, and Congress has refused to do that before." ${ }^{165}$ Similarly, before the ruling was issued, one attorney explained that "[i]f the ruling... knocks out mutual-fund annuities on the 'public access' question, [a]ll the company has to do is clone a fund that isn't available to the general public...." ${ }^{, 66}$ This attorney further predicted "that any IRS attack on the annuities will amount to nothing more than guaranteed employment for lawyers like me."167 Similarly, just one day following the issuance of Revenue Ruling 81-225, the New York Times reported on two methods that insurance companies could explore to avoid the ruling: First, the insurance companies could create and manage their own funds, ${ }^{168}$ and second, they could use clones of publicly available mutual funds. ${ }^{169}$

The rationale for the prohibition on public investments was to keep variable insurance products from seeming too investment oriented. This prohibition did not, however, affect variable contracts with a strong investment flavor so long as the new sourcing rule created by Revenue Ruling $81-225$ was observed. The tax agencies recognized that the investor control rulings left open the possibility of cloned funds. ${ }^{170}$ While it would have been possible to issue another revenue ruling extending the prohibition to investments that were too similar to publicly available funds, the Service determined that this would not be feasible. ${ }^{171}$ Instead, the Service began to impose diversification requirements on account funds by requiring certain representations in order to receive a favorable private letter ruling on the investor control issue. ${ }^{172}$ The Service tried out several different

${ }^{165}$ Bettner, supra note 147, at 56 (internal quotation marks omitted).

${ }^{166} I d$. (internal quotation marks omitted).

${ }^{167}$ Id. (internal quotation marks omitted).

168 Hayes, supra note 148 , at 36 ("[I]nsurance companies have the option of creating their own mutual funds and managing them independently.").

${ }^{169}$ Id. (describing idea of introducing clones); see also Petrie, supra note 85, at 113-14 (discussing ways in which insurance companies could avoid the ruling); Jill Bettner, IRS Attacks Popular 'Wraparound Annuities,' But Companies Ready New Tax-Deferral Plans, WALl ST. J., Sept. 28, 1981, at 56 (discussing the possibility of using clones to bypass the new revenue ruling).

${ }^{170}$ See Calhoun, supra note 23, at 779-80 (describing tax agencies' concern about clone funds).

171 See id. at 779 (describing Service's realization that "it could not police differences among mutual funds").

${ }^{172}$ The required representations were outlined in a private ruling. I.R.S. Priv. 
diversification rules with no apparent rationale guiding a particular diversification $\mathrm{mix},{ }^{173}$ although the overarching reason behind the new requirement was the belief that diversification would render it more difficult to use variable insurance contracts as a substitute for publicly available investments. ${ }^{174}$ In 1984 , Congress codified a diversification standard $^{175}$ and also provided Treasury with the authority to promulgate additional tests.

\section{E. Legislative Responses}

Following the rise of the wraparound insurance products, Congress determined to curtail privileges for contracts that were too investment oriented. The legislation enacted during the early 1980 s was aimed at both fixed and variable life insurance and annuity contracts. The specific reforms to life insurance and annuities took place in the shadow of the larger reform effort undertaken in 1986. This reform effort shut down many tax shelters. At the same time, the life insurance and annuity reforms did not end the tax deferral afforded to inside buildup. ${ }^{176}$ The combined effect of the overall reform and the new legislative certainty may actually have driven more investors into variable contracts, including wraparound

Ltr. Rul. 83-35-124 (May 27, 1983); see Service Notes Procedures for Obtaining Ruling on Wraparound Annuities, 20 TAx NoTES 770, 797 (Sept. 5, 1983) (describing the private ruling); see also Calhoun, supra note 23, at 779-80 (discussing diversification requirements imposed through letter rulings); Michael R. Levy \& Andrew H. Friedman, Insurance Companies Oppose Prohibition on Use of Government Securities to Fund Variable Annuity or Life Contracts, TAX NOTES TODAY (Nov. 28, 1986) (LEXIS, FEDTAX lib., TNT file, elec. cit., 86 TNT 236-40) (same); Skillman, supra note 1 , at $40-40$ (same).

${ }^{173}$ See also Calhoun, supra note 23, at 780 ("[T] he definition of what constituted diversification changed several times over this period."); Skillman, supra note 1, at 4040 (describing lack of clarity surrounding Service's rationale for the diversification requirements).

${ }^{174}$ See Kenneth M. Kess, Wrap-Around Annuities Maintain Tax Deferral Through Diversification, 13 J. TAX'N INV. 3, 6 (1995) (stating that the diversification requirement was imposed "to discourage the use of variable annuities and life insurance primarily as tax-motivated investment vehicles"); Levy \& Friedman, supra note 172 (explaining that diversification helped ensure that it would be more difficult to duplicate direct investments).

${ }^{175}$ Diversification was codified at the urging of Treasury and the Service. See Calhoun, supra note 23, at 781 (describing tax agencies' decision to seek codification of diversification).

${ }^{176}$ See Skillman, supra note 1, at 40-42 ("Congress has undertaken ... to confine life insurance and annuity contracts more or less to their traditional niches in the investment market."). 
contracts tied to insurance-only funds or clones of publicly available funds. ${ }^{177}$

\section{Life Insurance Changes}

The Tax Reform Act of 1984 added a definition of "life insurance" to the Code. ${ }^{178}$ The definition, still in effect, requires a

${ }^{177}$ For example, a training manual for insurance sellers stated:

The Tax Reform Act of 1986 effectively eliminated a number of tax shelters. Especially men and women in the higher income ranges have been left with few positive alternatives. However, life insurance was left virtually untouched by Tax Reform. Almost overnight, financial experts, many who had little to say about life insurance before, began to recognize its tax benefits.

VARIABle Universal LifE 42 (Egnar Jensen ed., 1988); see also Ellen E. Schultz, Investors are Flocking to Fund Cousins: Variable Annuities, WALl ST. J., Jan, 7, 1994, at R11 (the title speaks for itself); Michael Siconolfi, Tax Changes Spur InsuranceLinked Funds, WALL ST. J., Mar. 4, 1988, at 43 ("[M]utual fund assets in insurance products have grown fivefold in recent years...."); Karen Slater, Life Insurance's Appeal is Mixed Blessing; Firms Fear Tax Boon May Spur Washington Ire, WALL ST. J., Dec. 8, 1986, at 6 (explaining that as a result of 1986 tax law reform, investors "are turning to life insurance, that dreary old financial necessity, as an attractive investment"); Karen Slater, Variable Annuities, Life Insurance: Tax-Favored Investing - At a Price, Wall ST. J., Sept. 8, 1986, at 29 (explaining that if the then-proposed legislation was passed, variable contracts could "become one of the hottest products in the financial-services industry over the next few years").

178 I.R.C. $\$ 7702$ (a). There had been some movement by Congress in this area through the enactment in 1982 of temporary legislation, Code section 101(f). This provision applied only to flexible premium life insurance (e.g., universal life), and it imposed a test essentially identical to the guideline premium/cash value corridor test described infra notes 179-81 and accompanying text. For more discussion on old section 101(f), see Skillman, supra note 1, at 40-16 to 40-17; Thompson, supra note 39, at $54-55$.

Prior to the enactment of a statutory definition of life insurance, the principal authority in this area was the Supreme Court case of Helvering v. LeGierse, 312 U.S. 531 (1941). This case involved the question of whether proceeds from a life insurance policy were required to be included in the gross estate of the decedent. Id. at 537. At the time, there was a $\$ 40,000$ exemption for life insurance benefits payable to the estate. Id. at 538. The decedent, at the age of 80 , had purchased both an annuity contract and a life insurance policy from an insurance company. As a result, any mortality risk taken on by the insurance company through the life insurance policy was perfectly hedged by the annuity contract. The Supreme Court held that this arrangement did not constitute insurance because insurance must involve "riskshifting and risk-distributing." Id. at 539. Many articles have been written about LeGierse and the product purchased by the decedent in that case. See, e.g., David S. Miller, Distinguishing Risk: The Disparate Tax Treatment of Insurance and Financial 
contract to meet one of two complex tests, or the contract will be treated like a taxable investment account. ${ }^{179}$ Both tests use actuarial principles to control the ratio of cash value to death benefit. ${ }^{180}$ Although these new definitional requirements did somewhat restrict

Contracts in a Converging Marketplace, 55 TAX LAw. 481, 504-33 (2002). For accounts about the estate tax gambit at issue in LeGierse, see CLARK, supra note 22, at 36-37; Charles F. Dugan, Note, Taxation - Insurance and Annuity Contracts Under the Federal Estate Tax: Differentiation and Theories of Taxation, $38 \mathrm{MICH}$. L. REV. 526 (1940); Bruce H. Greenfield, Note, Federal Taxation of Combined Annuity and Life Insurance Contracts, 49 YALE L.J. 946 (1940); Note, Application of the Federal Estate Tax to Life Insurance Policies, 32 ILL. L. REV. 223 (1937); Note, Inheritance Taxes - Property Subject to Tax - What Is Insurance, 52 HARV. L. REV. 1180 (1939).

179 I.R.C. $\$ 7702(\mathrm{~g})$. Under this provision, the policyholder must treat as ordinary income the amount by which the net increase in the surrender value plus the life insurance costs exceeds the premiums paid during the year. I.R.C. $\& 7702(\mathrm{~g})(1)$. All prior years are also tainted, and the amount of any income from these prior years is treated as being received or accrued during the year the contract fails the definitional test. I.R.C $\$ 7702(\mathrm{~g})(1)(\mathrm{C})$. If the insured on a failed contract dies, the beneficiaries will be able to exclude from income only the amount of the death benefit that exceeds the net surrender value of the contract. I.R.C. $\$ 7702(\mathrm{~g})(2)$. If the failure to meet the definitional test is due to "reasonable error" and is corrected, then the Secretary may waive the failure. I.R.C. $\$ 7702(\mathrm{f})(8)$.

${ }^{180}$ The first test, known as the cash value accumulation test, was designed to allow traditional, level-premium cash value policies to qualify. See Skillman, supra note 1, at 40-18 (explaining that the cash value accumulation test "is primarily aimed at traditional whole life contracts"). In order to meet the cash value accumulation test, the amount of the cash surrender value may not exceed the net single premium that would be required to fund the future contract benefits. I.R.C. $\S 7702(b)(1)$. Several additional technical requirements apply, including provisions relating to interest rate assumptions and mortality charges. I.R.C. $\$ 7702(b)(2)$. For a more complete description of this test, see Pike, supra note 1, at 509-17.

The second test (which consists of two components, the guideline premium requirement and the cash value corridor) was intended to allow newer, flexible premium insurance products to qualify as life insurance. A contract will meet the guideline premium requirement component of this second test if the amount of the premiums paid does not exceed the greater of (1) the single premium that would be necessary to fund the future benefits under the contract (the "guideline single premium") or (2) the sum of the level premiums necessary to fund the future benefits and which would have been paid at the time the contract is tested (the "guideline level premiums"). I.R.C. $\$ 7702$ (c). In addition to meeting the guideline premium requirement, the contract must also fall within the cash value corridor specified in the Code. I.R.C. $\$ 7702(a)(2)$. This corridor specifies the minimum death benefit required at different ages of the insured. I.R.C. $\$ 7702(d)(2)$. This minimum death benefit is defined as a percentage of the cash value available under the contract. Id. Several highly technical additional requirements are imposed. For further discussion of this second test, see Skillman, supra note 1, at 40-18 to -21. 
the investment orientation of life insurance products, the deferral on inside buildup was essentially preserved. ${ }^{181}$ Congress also allowed the favorable treatment for life insurance distributions and loans to continue. ${ }^{182}$ That is, distributions from life insurance continue to be treated as nontaxable returns of investments first, and any excess is then taxed as ordinary income. ${ }^{183}$ In addition, loans tied to the cash surrender value are not treated as distributions. ${ }^{184}$

\section{Changes to Annuity Code Provisions}

In the Tax Equity and Fiscal Responsibility Act of 1982 (TEFRA), Congress amended the rules governing annuity distributions to reduce incentives for taxpayers to use these products as short-term investments. ${ }^{185}$ First, distributions from annuities that are not made as part of annuitization are now treated as coming first out of investment in the contract. ${ }^{186}$ Second, a ten percent penalty tax

${ }^{181}$ See Pike, supra note 1, at 576 (explaining that the new legislation was not a "systematic overhaul" and the inside buildup continued to receive deferral); Skillman, supra note 1, at 40-30 ("[T] he tax benefit of annuities consists almost entirely of deferral.").

${ }^{182}$ See supra Part II.B.

183 I.R.C. $\$ 72(\mathrm{e})(5)(\mathrm{A})$

184 I.R.C. $\$ 72(\mathrm{e})(5)(\mathrm{C})$. In 1988, Congress changed these rules for life insurance contracts with excessive front-loading of premiums. I.R.C. $\S 7702 \mathrm{~A}(\mathrm{~b})$. Such contracts allowed inside buildup to grow too large for Congress's taste. For these contracts, called "modified endowment contracts" (MECs), the annuity distribution and loan rules described infra Part III.E.2 apply instead. I.R.C. § 72(e)(10). In addition, a 10 percent penalty tax is imposed on MEC distributions unless they are made after the taxpayer has reached the age of $59 \mathrm{1} / 2$, the taxpayer has become disabled, or it is part of a "series of substantially equal periodic payments" for the life of the taxpayer. I.R.C. $\$ 72(\mathrm{v})$. The creation of the MEC category was likely triggered by the marketing of single-premium insurance as the last great tax shelter after the Tax Reform Act of 1986. See Slater, Life Insurance's Appeal is Mixed Blessing; Firms Fear Tax Boon May Spur Washington Ire, supra note 177, at 6 (explaining how insurance companies wished to downplay the role of single-premium policies as "the last of the big tax shelters" for fear that Congress would curtail their tax-preferred status).

185 See Goldberg \& Lemke, supra note 28 , at 450 (stating that changes to taxation of annuities "were designed to discourage the use of such annuities as short-term, taxsheltered investment vehicles").

${ }^{186}$ I.R.C. $\S 72(\mathrm{e})(1)-(3)$. However, no tax is imposed if the amount is kept as premium by the insurance company. I.R.C. $\S 72(\mathrm{e})(4)(\mathrm{B})$. Prior to TEFRA, the treatment was more favorable: withdrawals that were not regular annuity payments were taxed as though they came first from investment in the contract. See supra Part II.A. The Code distinguishes between distributions received as part of the 
applies to withdrawals made before the age of fifty-nine and onehalf. ${ }^{187}$ Finally, contract loans, assignments, or pledges of the annuity as collateral are to be treated as distributions. ${ }^{188}$

\section{Diversification Requirements for Variable Contracts}

In the Deficit Reduction Act of 1984 (DEFRA), Congress codified a diversification requirement for the accounts underlying all variable contracts, whether they are life insurance or annuity. ${ }^{189}$ The conference report relating to this enactment explained:

[T] he conference agreement allows any diversified fund to be used as the basis of variable contracts so long as all shares of the funds are owned by one or more segregated asset accounts of insurance companies, but only if access to the fund is available exclusively through the purchase of a variable contract from an insurance company.

The fact that a similar fund is available to the public will not cause the segregated asset fund to be treated as being publicly available. In authorizing Treasury to prescribe diversification standards, the conferees intend that the standards be designed to deny annuity or life insurance treatment for investments that are publicly available to investors and investments which are made, in effect, at the direction of the investor. ${ }^{190}$

This passage rejects the notion that funds "similar" to publicly

annuitization and those "not received as annuities." I.R.C. $\$ 72(\mathrm{e})(1)-(3)$. See supra note 65 .

${ }^{187}$ I.R.C. $\$ 72(q)$. The penalty tax was first set at 5 percent when enacted in 1982, but was raised to 10 percent in 1986. S. REP. NO. 97-248, at 1085 (1983); H.R. REP. No. 99-841, at 4541 (1987) (Conf. Rep.). In addition to the exception for distributions made after the age of $59 \mathrm{1} / 2$, several other exceptions are available, including payments made on disability of the taxpayer and death of the holder. I.R.C. $\$ 72(q)$.

${ }^{188}$ I.R.C. $\$ 72(\mathrm{e})(4)(\mathrm{A})$.

189 I.R.C. $\$ 817(\mathrm{~h})$. If any of the accounts underlying the variable contract fails to meet the diversification requirement, the entire contract is treated as failing to be life insurance for purposes of section 7702(a) or an annuity for purposes of section 72 . Id. Some relief is provided for inadvertent failures. See infra note 263.

${ }^{190}$ H.R. REP. No. 98-861, at 1055 (1986). The Service and Treasury generally cut the sentence referring to the availability of "similar fund" from their references to the legislative history. See, e.g., Rev. Rul. 2003-92, 2003-2 C.B. 350. 
available funds are also suspect. With its emphasis on public availability, this passage echoes the sourcing rule of investor control and also perpetuates the limited reach of that rule. ${ }^{191}$

The details of the diversification requirement are complex. ${ }^{192}$ The diversification requirement applies at the level of the "segregated asset account." Although initially there was some confusion about the meaning of this term, regulations have established that it refers to any underlying investment to which a contract holder may directly allocate premium or cash value. ${ }^{194}$ For example, if an individual purchases a variable annuity and is able to move premiums among a bond fund, equity fund, and fixed income fund, each of these funds would be considered a segregated asset account and would have to meet the diversification requirement.

Two safe harbors for meeting diversification have been created one statutory and the other regulatory. The statutory diversification safe harbor ${ }^{195}$ is derived from the diversification requirement imposed by the Code on regulated investment companies (mutual funds). ${ }^{196}$

191 See infra Part IV.

192 For additional information about the diversification requirements, see American Bar Ass'n, Committee on Insurance Companies, $A$ Roadmap to the Federal Income Taxation of Non-Qualified Annuity Contracts, 45 TAX LAW. 123 (1991).

193 The concept of "separate accounts" was added to the Code in 1962. See supra notes $35-36$ and accompanying text.

${ }^{194}$ Treas. Reg. $\$ 1.817-5(\mathrm{e})$, (g) Examples 1 \& 4 (1989); see also Stecker et al., supra note 6 (describing the development of the term "segregated asset account").

195 I.R.C. $\$ 817(\mathrm{~h})(2)$. Under the statutory safe harbor, at least fifty percent of the total assets in a segregated asset account must be represented by (1) cash, cash items, government securities, and interests in other mutual funds; and (2) other securities. I.R.C. $\$ 851(\mathrm{~b})(3)(\mathrm{A})$. As to the first group of items, an account may hold no more than 55 percent of such assets. I.R.C. $\S 817(\mathrm{~h})(2)(B)$. In addition, the investment in "other securities" is limited. The account may not have more than 5 percent of the total value of its assets invested in the securities of any one issuer, and the securities may not represent "more than 10 percent of the outstanding voting securities" of any one issuer. I.R.C. $\$ 851$ (b)(3)(A)(ii). There are also requirements governing assets purchased outside of the "at least 50 percent" rules. First, the account may not invest more than 25 percent of the value of its assets in the securities of one issuer, unless that issuer is the government or another mutual fund. I.R.C. $\S 851$ (b)(3)(B)(i). Second, if the account owns securities in two or more issuers that are engaged in similar trades or businesses, then no more than 25 percent of the value of the account's assets may be invested in such issuer groups. I.R.C. $\$ 851$ (b)(3)(B)(ii). Control for purposes of this test requires only that 20 percent of the ownership of the vote be owned by the account. I.R.C. $\$ 851$ (c)(2).

196 Regulated investment companies (RICs) are governed by Code sections 851 through 855 . Mutual funds that qualify as RICs are taxed essentially as pass-through 
The regulatory safe harbor, finalized in March $1989,{ }^{197}$ requires that an account must hold at least five investments in specified percentages. ${ }^{198}$

Key to understanding the relatively recent outbreak of hedge fund wraparound contracts is a regulation allowing accounts investing in certain pass-through entities to look-through to the assets held by such entities in determining whether the regulatory diversification test has been met. ${ }^{199}$ This look-through rule applies if all the beneficial interests in a mutual fund, partnership, or trust ${ }^{200}$ are owned only by the accounts of insurance companies and if "[p]ublic access" to the pass-through entity is available only through the purchase of a variable contract. ${ }^{201}$ There are, of course, exceptions to these requirements, ${ }^{202}$ one of which - recently repealed - spurred the

entities. See William Alfred Kern, Federal Income Taxation of Regulated Investment Companies, 42 NOTRE DAME LAW. 29, 33-34 (1966) (describing diversification requirements for RICs). For a more contemporary account of the tax treatment of mutual funds, see Alan L. Kennard, The Hedge Fund Versus the Mutual Fund, 57 TAX LAW. 133 (2003).

197 T.D. $8242,1989-1$ C.B. 215 . Section 817 (h) grants explicit authority to Treasury to promulgate diversification standards.

${ }^{198}$ Specifically, (1) "[n]o more than $55 \%$ of the value of the total assets of the account [may be] represented by any one investment," (2) no more than $70 \%$ in any two investments, (3) no more than $80 \%$ in any three investments, and (4) no more than $90 \%$ in any four investments. Treas. Reg. $\$ 1.817-5(b)(1)(i)(1989)$. For purposes of this test, "[a]ll securities of the same issuer, all interests in the same real property project, and all interests in the same commodity are each treated as a single investment." Treas. Reg. §1.817-5(b)(1)(ii)(A) (1989). In addition, each government agency is treated as a separate issuer if government securities are purchased. I.R.C. $\S 817$ (h)(6); Treas. Reg. § 1.817-5(b)(ii)(B) (1989).

${ }^{199}$ I.R.C. $\$ 817$ (h)(4); Treas. Reg. § 1.817-5(f) (1989).

200 Trusts treated as owned by the grantor under the Code only qualify for lookthrough treatment "if substantially all of the assets of the trust are represented by Treasury securities." Treas. Reg. \$1.817-5(f)(2)(iii) (1989).

${ }^{201}$ Treas. Reg. $\$ 1.817-5$ (f)(2)(i)(B) (1989); see Sheppard, supra note 12 ("Most insurers' segregated asset accounts attempt to satisfy the diversification rule ... by virtue of the look-through rules....").

${ }^{202}$ Four general exceptions apply. First, the general account of a life insurance company may hold a beneficial interest so long as a segregated asset account in the same insurance company also holds an interest in the entity, the return on the interest is computed in the same way for both the general account and the segregated asset account investor, and there is no intent to sell the interest in the pass-through entity to the public. Treas. Reg. $\$ 1.817-5(f)(3)$ (i) (1989). Second, a manager of the passthrough entity may hold a beneficial interest, but only if the interest was acquired "in connection with the creation or management" of the pass-through entity, the return on the interest is calculated the same for both the manager and the segregated asset account investors, and there is no intent to sell the interest to the public. Treas. Reg. $\S 1.817-5(f)(3)(i i)(1989)$. Third, a beneficial interest may be "[h]eld by the trustee of 
growth of hedge fund wrappers. The regulations provided that partnership interests qualified for look-through treatment if the partnership was "not registered under a Federal or State law regulating the offering or sale of securities," ${ }^{203}$ even though some interests were owned by non-insurance investors. Thus, contract premiums could be allocated solely to a hedge fund structured as a private placement partnership without failing diversification. ${ }^{204}$

a qualified pension or retirement plan." Treas. Reg. \$1.817-5(f)(3)(iii) (1989). Finally, a beneficial interest may be held by members of the public, or those who are treated as public policyholders under Rev. Rul. 81-225, if the investment entity was closed to the public in accordance with Rev. Rul. 82-55 or if all the assets of the segregated asset account are attributable to either premium payments made by policyholders prior to Sept. 26, 1981, to premium payments made in connection with a qualified pension or retirement plan, or to any combination of such premium payments. Treas. Reg. § 1.817-5(f)(3)(iv) (1989).

In response to recent Treasury requests for comments about these exceptions, several practitioners have urged expanding these exceptions. In particular, numerous commentators urged repealing the restriction requiring managers to hold only interests yielding the same return as other interests in the investment entity. See infra notes $265-67$ and accompanying text.

${ }^{203}$ Treas. Reg. $\$ 1.817-5(\mathrm{f})$ (2)(ii) (1989). As described infra notes 235-37 and accompanying text, this provision is excised from the proposed regulations issued on July $30,2003$.

${ }^{204}$ It is not clear the extent to which Treasury was aware of the problem it was creating. But see Hugh T. McCormick, Attorney Requests Additional Guidance on Investments Held Under Variable Life Insurance Contracts, TAX NOTES TODAY n.5 (Feb. 26, 2003) (LEXIS, FEDTAX lib., TNT file, elec. cit., 2003 TNT 38-25) (stating "[i]t is thus difficult to construct a credible argument that the rule for non-registered partnerships was not fully considered, or that it represents a 'loophole"). This exception for unregistered partnerships was apparently put in place at the insistence of real estate groups:

This exception, installed in 1988 at the behest of a particular insurer, was intended to permit investment in real estate limited partnerships whose managers were being compensated over and above investment returns. That is, it was intended as relief from the rule of reg. section 1.817$5(\mathrm{f})(3)(\mathrm{ii})$, which restricts fund manager compensation to investment returns computed on the same basis as they are for investors.

But reg. section 1.817-5(f)(2)(ii) is not restricted in any way; it just speaks of partnerships that are not registered with federal or state securities regulators. So planners have taken the bit in their teeth and run with it.

Sheppard, supra note 12 . In response to recent Treasury requests for comments, practitioners have particularly complained that the requirement that a managers' interest be calculated the same for both manager and the segregated asset account creates a situation in which it will be difficult to create all insurance private investment partnerships. See infra notes $265-67$ and accompanying text. Given the 
As described in the next section, some companies argued that the investor control rulings had been superseded by this regulation even though Treasury had noted in its preamble to the initial, temporary diversification regulations that it intended to leave the "investor control" question open. ${ }^{205}$ In addition, Treasury and Service officials repeated their opinion on the continued vitality of investor control throughout the $1990 \mathrm{~s}^{206}$ but took no new action on investor control until 2002, when it became apparent that taxpayers were using the diversification regulations to justify the wrapping of private placement hedge funds inside variable insurance interests.

\section{F. Hedge Fund Wrappers}

Hedge funds ${ }^{207}$ had not yet attained full prominence when the

results of creating the original exception for private placement partnerships, the regulations finalized March 1, 2005, did not change the pro rata requirement for managers. See infra notes $238-40$ and accompanying text.

${ }^{205}$ The preamble provided as follows:

The temporary regulations in this document do not address any issues other than the diversification standards.... In particular, they do not provide guidance concerning the circumstances in which investor control of the investments of a segregated asset account may cause the investor, rather than the insurance company, to be treated as the owner of the assets in the account. For example, the temporary regulations provide that in appropriate cases a segregated asset account may include multiple subaccounts, but do not specify the extent to which policyholders may direct their investments to particular sub-accounts without being treated as owners of the underlying assets. Guidance on this and other issues will be provided in regulations or revenue rulings under section $817(\mathrm{~d})$, relating to the definition of variable contract.

T.D. 8101, 1986-2 C.B. 97 reprinted in TAX NoTES TODAY (Sept. 15, 1986) (LEXIS, FEDTAX lib., TNT file, elec. cit., 86 TNT 184-31); see also AMERICAN BAR Ass'N , supra note 192, at n.74 (describing the preamble to the proposed regulations).

${ }^{206}$ In 1999, for example, the Service issued Rev. Proc. 99-44, 1999-2 C.B. 598, which described the circumstances under which certain plan annuity contracts would be treated as qualified, "notwithstanding that contract premiums are invested at the direction of the contract holder in publicly available securities." See also Anthony Calabrese, Attorney Comments on Proposed Regs on Annuity Contracts, Life Insurance, TAX NOTES TODAY (Dec. 5, 2003) (LEXIS, FEDTAX lib., TNT file, elec. cit., 2003 TNT 234-13) (discussing other private letter rulings signaling the tax agency's intent to preserve investor control); Marlis L. Carson, IRS's HOOE Outlines Recent Insurance Taxation Guidance, TAX NOTES TODAY (Oct. 17, 1994) (LEXIS, FEDTAX lib., TNT file, elec. cit., 94 TNT 203-6) (describing a private letter ruling that "reaffirmed the relevance of the investor control doctrine").

${ }^{207}$ Hedge funds are usually organized as private investment partnerships. 
diversification regulations were adopted, ${ }^{208}$ but by mid-1998 it was estimated that "there were between 2,500 and 3,500 hedge funds managing between $\$ 200$ billion and $\$ 300$ billion in capital, with approximately $\$ 800$ billion to $\$ 1$ trillion in total assets. ${ }^{, 209}$ The linkage of variable contracts and hedge funds began in earnest in the late 1990s. ${ }^{210}$ In 2001, articles describing hedge fund insurance wrappers began appearing in both specialized tax publications and mainstream news outlets. ${ }^{211}$ In a letter ruling made available to the public in

Generally, they invest in a wide variety of sophisticated financial instruments. See STAFF REPORT TO THE U.S. SECURITIES AND EXCHANGE COMMISSION, IMPLICATIONS OF THE GROWTH OF HEDGE Funds, 3 (2003) [hereinafter SEC REPORT] (describing types of financial instruments in which hedge funds invest); REPORT OF THE PREsident's Working Group on FinANCIAL Markets, Hedge Funds, LeVerage, AND THE LESSONS OF LONG-TERM CAPITAL MANAGEMENT 2-3 (1999) [hereinafter WORKING GROUP REPORT] (describing the various strategies and financial instruments used by hedge funds); Kennard, supra note 196, at 158-59 (describing offshore hedge funds).

Hedge fund interests are offered through private placements to wealthy investors in order to minimize regulatory oversight by federal and state securities agencies. See SEC REPORT, supra at 11-32. Although hedge fund interests are "securities" for purposes of federal securities laws, hedge funds typically avoid registration requirements through private placement exceptions. See id. at ix-x (summarizing exclusions relied on by hedge funds to avoid registration). In a recent report, SEC staff recommended that hedge fund advisers should be required to register as investment advisers. Id. at xi. This recommendation was adopted in December 2004. Registration Under the Advisers Act of Certain Hedge Fund Advisers, 69 Fed. Reg. 72,054 (Dec. 10, 2004).

${ }^{208}$ See WORKING GROUP REPORT, supra note 207, at 1 (stating that the first hedge fund "is conventionally dated to 1949" and that a 1968 survey "identified 140 funds"); Gary Weiss, Fall Guys? Mysterious and Vilified, Hedge Funds Are Also the Street's Trailblazers, Bus. WK., April 25, 1994, at 116, 120 (explaining that hedge funds "have been around for more than four decades").

209 WORKING GROUP REPORT, supra note 207, at 1 . When compared with the rest of the financial market, however, this was a relatively small sector. Id. at 1-2 (comparing hedge funds to other sectors). The SEC recently reported, "[i]t is estimated that there are now approximately $\$ 870$ billion of assets in approximately 7000 funds." Registration Under the Advisers Act of Certain Hedge Fund Advisers, 69 Fed. Reg. 72,054, 72,055 (Dec. 10, 2004).

${ }^{210}$ Allison Bisbey Colter, Insurers Provide Access to Hedge Funds, WALL ST. J., Oct. 2, 2001, at B7F ("It wasn't until private placement policies were pitched to wealthy individuals in the mid- to late-1990s that anyone recognized the potential tax benefits to hedge-fund investors.").

211 Id. (describing the development of this product); see also Schizer, supra note 9, at 1388-89 ("II]nsurance is becoming an increasingly common method of securing tax advantaged hedge fund returns."); Sheppard, supra note 11 (describing hedge fund wrappers). 
November 2002, the Service used the investor control doctrine to attack one method of wrapping hedge fund interests inside variable insurance contracts. ${ }^{212}$

The taxpayer insurance company ${ }^{213}$ described in the ruling had been offering contracts allowing the contract holder to allocate premium to a number of hedge funds organized as private placement partnerships. $^{214}$ The company argued that the look-through diversification rule for private placement partnerships was "evidence" that the contract qualified "for favorable tax treatment"

Two articles written in 1998, although not explicitly about wraparound annuities holding hedge fund interests, suggest the availability of this technique. Bridget O'Brian, Annuity Countertrend: Investors Can Choose Their Own Features, WALL ST. J., Jan. 8, 1998, at R10 (describing "custom-made annuit[ies]"); Bridget O'Brian, Offshore Annuities Give Benefit of Privacy, WALL ST. J., Jan. 26, 1998, at C18 (describing hedge fund managed, offshore annuities being used as tax shelters).

In addition, more general warnings about insurance wrappers were made in the late 1990s. See Sheppard, supra note 52, at 735 ("Life insurers have figured out how to wrap any conceivable financial product inside a tax-favored life insurance or annuity contract ...."); Stecker et al., supra note 6 (warning that products "flirt[ing]" with investor control "could destroy the tax-deferral feature associated with these products").

${ }^{212}$ I.R.S. Priv. Ltr. Rul. 2002-44-001 (May 2, 2002). The issuance of the private letter ruling was known even before it was released to the public. See John D. McKinnon, U.S. May Curtail Hedge-Tax Haven Tied to Insurance, Wall ST. J., Sept. 12,2002 , at A10 (describing threatened "crackdown" by Treasury on hedge fund insurance arrangements); Sheppard, supra note 12 (describing the ruling before it was publicly released).

The issuance of a negative letter ruling is a fairly rare occurrence because the taxpayer has the opportunity to withdraw the ruling request before a negative ruling is issued. DODGE ET AL., supra note 113, at 100 (explaining that taxpayers may withdraw requests to avoid issuance of an unfavorable ruling). The taxpayer in this case did ask for reconsideration. See Jon Almeras, Treasury Official, Practitioners Discuss Hedge Fund Letter Ruling, 97 TAX NOTES 1002, 1003 (Nov. 25, 2002) (describing request for reconsideration by taxpayer's attorney). Since less aggressive practitioners advised clients against relying on the look-through rule for private placement partnerships to avoid investor control, one wonders why a private letter ruling was sought in the first place. See Sheppard, supra note 12 (stating that "more conservative law firms" would not issue legal opinions on hedge fund wrappers).

${ }^{213}$ The taxpayer was Keyport Life Insurance. Allison Bisbey Colter, Hedge Funds Encounter Tax Hurdles, WALL ST. J., Dec. 18, 2002, at B7C.

${ }^{214}$ The contracts did specify that "[n]o Contract owner may be a general partner or an investment manger of a PIP.... In addition, no Contract owner may independently hold any interest in a PIP . ..." I.R.S. Priv. Ltr. Rul. 2002-44-001 (May 2 , 2002). These requirements mitigated the possibility that the facts-andcircumstances test of investor control would apply.

215 I.R.S. Priv. Ltr. Rul. 2002-44-001 (May 2, 2002). Treasury ended this 
underlying assets of the segregated asset account are not available to the general public because the [hedge fund interests] are limited to purchase by only certain investors." "216 The insurance company asserted that the investment available "inside" the insurance contract and "outside" the contract were not "substantially identical": "[T]he death benefit provisions (and mortality charges) create material economic differences between the direct ownership of any asset and the ownership of that asset through a variable life insurance contract." ${ }^{217}$ Similarly, the company contended that the enactment of a definition of "life insurance contract" in 1984 precluded "the application of the investor control theory to assets held by a life insurance company under a life insurance contract that satisfies the requirements of section $7702 . " 218$

The Service rejected the contention that the look-through diversification regulation allowed the taxpayer to circumvent investor control. ${ }^{219}$ The hedge fund interests were publicly available in the colloquial sense if not in the SEC sense. In addition, the Service noted that legislative history indicated congressional intent to "deny annuity or life insurance treatment for investments that are publicly

argument by issuing proposed regulations that would repeal the regulation relied on by these companies. Internal Revenue Service, supra note 113. In the preamble to the recently proposed regulations, Treasury explained, "Congress intended to treat qualified purchasers and accredited investors as part of the general public when determining whether an investment is available for the purchase by the general public." Id.

${ }^{216}$ I.R.S. Priv. Ltr. Rul. 2002-44-001 (May 2, 2002).

${ }^{217}$ Id. The factual variations in Rev. Rul. 81-225 all described annuities. See supra Part III.D.

${ }^{218}$ I.R.S. Priv. Ltr. Rul. 2002-44-001 (May 2, 2002); see also AMERICAN BAR Ass'N, supra note 192, at 137 (asserting that the investor control rulings were "enforced through the ... diversification requirements"); Calabrese, supra note 206 (explaining that "some practitioners took the position that the previous investor control rulings were mooted" by the diversification requirement); Frederic J. Gelfond, 2003 Insurance Tax Year in Review: Part II - Product Tax Matters, TAX NOTES TODAY (Feb. 26, 2004) (LEXIS, FEDTAX lib., TNT file, elec. cit., 2004 TNT 38-60) (explaining argument made by some "that the diversification requirements adopted by Congress in 1984 rendered the investor control doctrine obsolete"); Neufeld, supra note 114 (arguing that combination of statutory and regulatory law allowed insurance accounts to invest in publicly available hedge funds); Stecker et al., supra note 6 (stating that it was "unclear whether Congress also intended the diversification requirements to actually supersede those [investor control] rulings").

${ }^{219}$ The Service cited the preamble to the original temporary regulation. See supra note 205 and accompanying text. 
available to investors." ${ }^{220}$ The Service cited the various investor control rulings described above $\mathrm{e}^{221}$ and held:

[T]he interests in [the hedge funds] that support the Contracts' sub-accounts are available for purchase... by other members of the general public. Treating the Contract holders as the owners of interests in [the hedge funds] ... is consistent with Congress' intent to deny annuity or life insurance treatment for investments that are publicly available to investors. ${ }^{222}$

As occurred following the issuance of the mutual fund wrapper revenue ruling, insurance-only funds were quickly discussed as one way to avoid the letter ruling. For example, an article in the Wall Street Journal explained that this private letter ruling meant that "[i]n effect... hedge-fund advisers are no different from mutual-fund companies, which have to set up separate 'clone' funds to sell through insurance contracts, ${ }^{, 223}$ and which would make the ability to wrap hedge funds more expensive. ${ }^{224}$

In the summer of 2003, the Service and Treasury formalized their position by issuing a new investor control revenue ruling as well as proposing amendments to the diversification regulations. ${ }^{225}$ Revenue

220 This legislative history is quoted at note 190 supra and accompanying text.

221 See supra Part III.E.

222 I.R.S. Priv. Ltr. Rul. 2002-44-001 (May 2, 2002).

${ }^{223}$ Colter, supra note 213 , at B7C.

${ }^{224}$ Id. ("Wrapping insurance contracts around hedge funds that also are available to taxable investors is much cheaper, and the investment minimums tend to be lower."); see also McCormick, supra note 204 (explaining that the "principal effect" of any change to the look-through rule for non-registered partnerships "would be to allow existing practices to continue in a slightly modified, if more expensive, form"); Lee A. Sheppard, Hedge Fund Wrapper Ruling Complicates Reaching Smaller Investors, TAX NOTES TODAY (Nov. 5, 2002) (LEXIS, FEDTAX lib., TNT file, elec. cit., 2002 TNT 214-2) (stating that the letter ruling would mean the companies would "have to persuade hedge fund managers to set up special funds for them").

${ }^{225}$ The proposed regulations were finalized on March 1, 2005. Internal Revenue Service, IRS Publishes Final Regs on Look-Through for Nonregistered Partnerships, TAX NOTES TODAY (Mar. 1, 2005) (LEXIS, FEDTAX lib., TNT file, elec. cit., 2005 TNT 39-10).

Several practitioners had urged Treasury to formalize its position. See, e.g., Richard W. Skillman, Attorney Urges Adoption of Regs on Investments Held Under Variable Life Insurance Contracts, TAX NOTES TODAY (Jan. 9, 2003) (LEXIS, FEDTAX lib., TNT file, elec. cit., 2003 TNT 6-35). 
Ruling $2003-92^{226}$ is strikingly similar to Revenue Ruling $81-225,{ }^{227}$ and it describes three factual situations. In the first, a variable annuity provided contract holders the right to allocate premiums among ten partnerships, whose interests were sold only through private placement offerings to qualifying investors. ${ }^{228}$ The annuity contract did provide that a contract holder could not "act as an investment manager or independently own any interest in any [p]artnership offered" under the annuity. ${ }^{229}$ The second situation was identical to the first except that it involved a life insurance contract instead of an annuity. ${ }^{230}$ The third situation repeated the first and second situations except that the partnership interest could only be purchased through an annuity or life insurance contract. ${ }^{231}$

Revenue Ruling 2003-92 held that only the final situation was permissible, and thus is a reaffirmation of Revenue Ruling 81-225's prohibition on publicly available investments. ${ }^{232}$ Revenue Ruling 2003-92 cites to and describes the primary investor control authorities discussed in this article; however, the Ruling contains little actual explanation for its outcome. It states only that in the first two situations the accounts "hold interests in Partnerships for purchase other than by purchasers of [annuity or life insurance contracts] from insurance companies. Therefore, for federal income tax purposes, Contract Holder is the owner of the interests in Partnerships...."233 As to the third situation, because the accounts held interests in partnerships that could only be purchased through an annuity or life insurance contract, the partnerships were considered owned by the insurance company rather than the contract holder. ${ }^{234}$

${ }^{226}$ This ruling was issued under section 61(a). See David S. Neufeld, New Guidance on Investor Control Rule: Road Map or Roadblock?, TAX NOTES TODAY (Sept. 3, 2003) (LEXIS, FEDTAX lib., TNT file, elec. cit., 2003 TNT 170-29) (positing that the ruling could not be issued under section 817 (d) given the existence of the look-through regulation for nonregistered partnerships).

${ }^{227}$ See supra Part III.D.

${ }^{228}$ Rev. Rul. 2003-92, 2003-33 I.R.B. 350.

${ }^{229}$ Id.

${ }^{230} I d$.

${ }^{231} I d$.

${ }^{232} I d$.

${ }^{233}$ Id.

${ }^{234}$ Revenue Ruling 2003-92 was issued with a companion ruling, Revenue Ruling 2003-91. Rev. Rul. 2003-91, 2003-33 I.R.B. 347. This ruling contained a description of another "good facts" situation involving investor control. In this ruling, multiple subaccounts, up to twenty, were available to which contract holders could allocate premiums. Id. Each subaccount had a different investment strategy, including 
Shortly after Revenue Ruling 2003-92 was released, Treasury also issued proposed regulations removing the look-through diversification provision for private placement partnerships. The preamble to the regulations described the look-through rule for nonregistered partnerships as "not consistent with Congressional intent because it is not explicitly subject to the public availability limitation of section $817(\mathrm{~h}) ., 235 \quad$ The preamble also described hedge fund wrapper arrangements and explained:

Taxpayers that purchase a variable annuity or life insurance contract are indirectly investing in partnership interests that are available for direct investment by the general public. By indirectly investing in these partnership interests through the purchase of a variable contract taxpayers defer tax on partnership earnings that might otherwise be currently taxable. The Treasury Department and the IRS believe that these arrangements (often marketed as "insurance wrappers") are the type of overly investment oriented insurance and annuity arrangements that Congress sought to prevent when it enacted the diversification rules of section $817(\mathrm{~h}) .^{236}$

These regulations were finalized on March 1, 2005. ${ }^{237}$ The final regulations were little changed from the proposed regulations. ${ }^{238}$

strategies as specific as "a South American stock fund, an energy fund and an Asian markets fund." Id. The subaccount funds were accessible only through purchase of an annuity or life insurance contract. Id. The ruling also emphasized the lack of an agreement as to investment management between the contract holder and the insurance company. Id.

Revenue Ruling 2003-91 is similar to Revenue Ruling 82-54. See supra notes 160-63 and accompanying text. Revenue Ruling 2003-91, however, amplifies Revenue Ruling 82-54 by its allowance of up to twenty funds with investment strategies significantly narrower than those in Revenue Ruling 82-54 (e.g., "Asian markets fund" compared to a common stocks fund). Revenue Ruling 2003-91 does not address whether twenty is the maximum number of funds permissible without triggering investor control or otherwise discuss the significance of the number of funds. For additional discussion of Revenue Ruling 2003-91, see Neufeld, supra note 226.

235 Internal Revenue Service, supra note 113.

${ }^{236} I d$.

${ }^{237}$ Internal Revenue Service, supra note 225.

${ }^{238}$ The other changes were technical corrections meant to bring the examples and definitions into conformance with the changes. For example, the definition for "security" had to be revised also to include interests in a nonregistered partnership. 
Importantly, the final regulations did not change the requirements for beneficial ownership in an underlying investment. Under a regulatory exception to the requirement that all ownership be held by insurance companies, managers may hold interests in the underlying investment entity, but only if their return on the interest is calculated in the same way as all the other interests in the entity. ${ }^{239}$ In response to the proposed regulations' request for comments, several practitioners urged that the requirement that a manager's interest be calculated the same for both the manager and the segregated asset account creates a situation in which it will be difficult to create insurance-only private investment partnerships. ${ }^{240}$ The inability to provide hedge fund managers with better returns than those available to the insuranceaccount investors may act as a tax avoidance deterrent. ${ }^{241}$

The Treasury press releases issued in connection with the new

Id. The final regulations did allow taxpayers two additional calendar quarters in which to meet the revised diversification requirements. The original date was the last day of the second calendar quarter after the effective date of the regulations, which was the finalization date. Internal Revenue Service, supra note 113. Thus, taxpayers will have until December 31, 2005, to bring their products into conformance with the amended diversification regulations. Internal Revenue Service, supra note 225.

239 See supra note 202.

${ }^{240}$ See Calabrese, supra note 206 (pointing out private investment partnerships' reliance on this exception); Davis \& Harman LLP, Annuity Insurers Comment on Investment Diversification Requirements, TAX NOTES TODAY (Oct. 30, 2003) (LEXIS, FEDTAX lib., TNT file, elec. cit., 2003 TNT 210-52) (arguing that the proposed regulations "effectively preclude any potential for abuse of the General LookThrough Rule, without the need for the current rule requiring that the return on an investment manager's interest be determined on an equal, pro rata basis with the return on a segregated asset account's interest"); Dwight W. Ellis, III \& Andrew W. Needham, New Regs on Investor Control Rules: Concerns With the Road Map, TAX NOTES TODAY (Sept. 23, 2003) (LEXIS, FEDTAX lib., TNT file, elec. cit., 2003 TNT 184-46) (noting that "[u]nder the new regime, therefore, a wrapped fund with an incentive allocation cannot qualify for 'look through' treatment"); Laurie D. Lewis \& Lisa Tate, ACLI Suggests Modified Effective Date for Proposed Regs Targeting Insurance as Tax-Avoidance Vehicle, TAX NOTES TODAY (Nov. 12, 2003) (LEXIS, FEDTAX lib., TNT file, elec. cit., 2003 TNT 218-27) (arguing that "[n]on-pro-rata distributions of the investment returns of segregated accounts should be permitted to take account of certain bonus payments to investment managers commonly referred to as incentive payments"); John E. Tavss \& Daniel C. Murphy, Attorneys Suggest Revised Look-Through Rule for Regs on Life Insurance, Annuity Contracts, TAX Notes TOdAy (Nov. 13, 2003) (LEXIS, FEDTAX lib., TNT file, elec. cit., 2003 TNT 219-48) ("[U]nless the Identical Computation Requirement is eliminated from the Regulations, it is likely that policyholders would be unable to access many private investment partnerships.").

${ }^{241}$ See infra notes $265-67$ and accompanying text. 
investor control revenue ruling and proposed regulations were on the self-congratulatory side: $:^{242}$ " [ $\left.\mathrm{t}\right]$ he regulation, together with Revenue Ruling 2003-92 issued on July 23, 2003, will prevent taxpayers from turning otherwise taxable investments in hedge funds and other entities into tax-deferred or tax-free investments merely by purchasing the investments through a life insurance or annuity contract. ${ }^{243}$

A Wall Street Journal article cited one attorney's reaction to the revenue ruling: "[m]any investors and their insurance brokers 'may not be sleeping too well tonight.", ${ }^{244}$ However, the article also provided U.S. Representative Richard Neal's assessment: "[u]nfortunately, I'm sure these clever promoters will be back next week with another investment vehicle disguised as insurance."245

${ }^{242}$ See Treasury Department, Treasury Announces Efforts to Curb Abuse of Life Insurance, Annuity Contracts, TAX NOTES TODAY (July 24, 2003) (LEXIS, FEDTAX lib., TNT file, elec. cit., 2003 TNT 142-23) (release for revenue rulings); Treasury Department, Treasury, IRS Propose Reg to Limit Abuse of Life Insurance, Annuity Contracts, TAX NOTES TODAY (July 30, 2003) (LEXIS, FEDTAX lib., TNT file, elec. cit., 2003 TNT 146-34) (release for proposed regulations). Treasury continued to tout the issuance of these authorities well into 2004. See Treasury Department, Treasury Commends Bush Administration Approach to Curbing Tax Shelters, TAX Notes TODAY (Feb. 20, 2004) (LEXIS, FEDTAX lib., TNT file, elec. cit., 2004 TNT 34-19) (describing administration action "to stop abusive transactions and eliminate potential opportunities for abuse," including the issuance of Rev. Rul. 2003-92).

${ }^{243}$ Treasury Department, Treasury, IRS Propose Reg to Limit Abuse of Life Insurance, Annuity Contracts, supra note 242. A writer for Tax Notes Today described the Treasury release as "trumpet[ing] the rulings as tools to prevent taxpayers from using insurance products and insurance companies as a means to shelter income from current taxation." Jon Almeras, IRS Issues Formal Guidance on Investor Control for Variable Contracts, TAX NOTES TODAY (July 24, 2003) (LEXIS, FEDTAX lib., TNT file, elec. cit., 2003 TNT 142-4); see also David Lupi-Sher, IRS Issues Regs to Limit Abuse of Life Insurance, Annuity Contracts, TAX NOTES TODAY (July 30, 2003) (LEXIS, FEDTAX lib., TNT file, elec. cit., 2003 TNT 146-2) (describing news release on proposed regulations).

A practitioner comment, also published in Tax Notes Today, was particularly strongly worded, stating that the release triggered "inaccurate reporting fostered by Treasury.... No one asked if it really does what Treasury said it does or if there is really any abuse at all. Sometimes it is not the weapons you have, but the weapons the other side thinks you have that make all the difference." Neufeld, supra note 226. For comments disagreeing with Neufeld, see Ellis \& Needham, supra note 240 (stating that "[i]n the vast majority of cases, the proposed regulations... will invalidate insurance policies that wrap hedge fund investments").

${ }^{244}$ Tom Herman \& Theo Francis, Tax-Avoidance Device is Attacked, WALL ST. J., July 24, 2003, at D2.

${ }^{245}$ Id. As to the reaction when the regulation was proposed, see Treasury Seeks 
Indeed, there does appear to have been a collective shrug among practitioners in this area when the 2003 ruling was issued. ${ }^{246}$ The reason was that insurance companies had already figured out their next moves. ${ }^{247}$

The same two techniques available following the investor control rulings and legislation of the 1980s remain. Under the terms of the 2003 ruling, an insurance account is still permitted to invest in a hedge fund, so long as all of the interests are owned by other insurance accounts. In addition to creating insurance-only hedge funds, clones of publicly available hedge funds can still be created without technically running afoul of the new revenue rulings or proposed regulation. ${ }^{248}$ Finally, one writer has suggested that there would be no prohibition on a variable contract holding a derivative linked to a hedge fund. ${ }^{249}$ Perhaps a derivatives wrapper will be the next iteration of the wraparound shelter to emerge.

to Restrict Insurance-Linked Tax Moves, N.Y. TimES, July 31, 2003, at C5.

${ }^{246}$ See Almeras, supra note 243 (explaining that "because the rulings aren't surprising, they won't change the marketplace").

${ }^{247}$ The Treasury's announcement was not unexpected. As described supra notes 212-24 and accompanying text, in 2002, the Service released a private letter ruling applying the investor control rule to variable insurance hedge fund investments. I.R.S. Priv. Ltr. Rul. 2002-44-001 (May 2, 2002); see Neufeld, supra note 226 (explaining that after the issuance of letter ruling 2002-44-001, "most reputable insurance companies" changed practices in order to comply with the private ruling).

${ }^{248}$ As briefly described, supra note 169 , the use of clones, or close clones, is already common in the mutual fund area and has been for some time. See Ellen E. Schultz, Fund Track: Variable Annuity 'Minimarts' Now Feature Big Brand Names, WALl ST. J., July 31, 1996, at C1 (describing the availability of brand-name mutual funds inside variable insurance products); Ellen E. Schultz, Your Money Matters: Variable Annuities Provide the Choices of Mutual Funds, Plus Some Tax Breaks, Wall ST. J., Oct. 14, 1993, at C1 (same); cf. David Franecki, Annuity Clones of Mutual Funds Warned, WALL ST. J., May 26, 1998 at C22 (describing a case involving improper labeling of funds underlying variable annuities); Vanessa O'Connell, Annuity Funds and Namesakes May Differ, WALL ST. J., April 6, 1998, at B1 (warning investors to be wary of the inaccurate use of brand-name mutual funds when buying into variable insurance).

${ }^{249}$ Michael A. Heimos, Attorney Critiques Regs Targeting Use of Annuity Contracts, Life Insurance As Tax Avoidance Vehicles, TAX NOTES TOdAY (Oct. 30, 2003) (LEXIS, FEDTAX lib., TNT file, elec. cit., 2003 TNT 210-51) ("[N]othing prevents the indexing of an insurance segregated asset account to a known hedge fund, perhaps even by the same manager or managers of the hedge fund where such are hired by an insurance company to manage an unorganized pool of assets."). The success of this technique will depend in part on who is considered the issuer of the derivative. See infra note 293. 


\section{THE EFFICACY OF THE AgENCIES' LEGAL FRAMEWORK}

The contrast between the claims made by the tax agencies and those made by the insurance industry regarding investor control and diversification illustrates the contours of a troubling, but stable, truce surrounding wraparound insurance contracts. Since 1981, members of the insurance industry have claimed that a cloned fund is sufficient to avoid both aspects of the investor control doctrine. ${ }^{250}$ In doing so, they implicitly assert that the agencies' restrictions impose relatively minimal burdens on the wraparound technique. ${ }^{251}$ To be sure, insurance companies do complain about the burdens imposed by the investor control doctrine and the diversification requirement, but their reactions, particularly after the rulings issued on mutual fund wrappers and hedge fund wrappers, have sounded more in scorn than submission.

The tax agencies, on the other hand, have asserted that the investor control doctrine and diversification requirement are strong weapons in their war on tax shelters. Their press releases following the issuance of proposed regulations and recent investor control rulings, for example, were self-congratulatory (even though the agencies were fixing a problem largely of their own creation). ${ }^{252}$ Although this is the public position of the tax agencies, they are, of course, aware that investor control and diversification fail to shut

${ }^{250}$ Some private letter rulings have been issued suggesting the permissibility of clone funds. See I.R.S. Priv. Ltr. Rul. 84-03-014 (Oct. 11, 1983) (noting that account fund had "the same general investment objectives and essentially the same investment policies and procedures" of public mutual funds); I.R.S. Priv. Ltr. Ruls. 94-22-006 through 94-22-012, 94-22-014 (Feb. 24, 1994) (all stating that there was no "public access" to insurance account fund even though the fund would have the same investment objective, investment advisor, principle underwriter and administrator as a public fund); I.R.S. Priv. Ltr. Rul. 98-47-017 (Aug. 21, 1998) (describing in context of a diversification ruling account fund that would have "the same as the investment objectives and strategies" of a publicly available fund); Gordon O. Pehrson et al., 546 T.M., Annuities, Life Insurance, and Long-Term Care Insurance Products A-51 (2003) (asserting the argument that insurance-only clones should work to avoid investor control).

The Service did, however, issue new letter rulings that deleted some of the paragraphs that would have more clearly allowed clones. See I.R.S. Priv. Ltr. Rul. 9437-026 (June 17, 1994) (deleting paragraph about "public access" in rulings 94-22-006 through 94-22-012 and 94-22-014 and adding, "[n]o opinion was expressed as to the ownership, for tax purposes, of the assets in each [segregated asset account]").

${ }^{251}$ See Heimos, supra note 249 (explaining that "the status quo can continue in substance, though at an increased (but probably not prohibitive) cost").

${ }^{252}$ See supra Part III.E.3. 
down completely the wraparound insurance tax shelter. For example, one individual associated with the drafting of Revenue Ruling 81-225 explained that investor control was intended to increase the price of the shelter in order to reduce revenue losses and move the technique into fewer hands. ${ }^{253}$

As the insurance industry contends - and the tax agencies may privately concede - the investor control doctrine and diversification requirement leave room for insurance companies to craft substitute wraparound insurance contracts for their wealthiest clients (although recent changes in the diversification regulations introduced a friction $^{254}$ that may dampen the technique for a time ${ }^{255}$ ). Arguably, the tax agencies could do more to burden wraparound insurance contracts without overstepping statutory constraints. Increasing the burden on wraparound contracts, however, would be a politically difficult move given the strength of the insurance lobby and one that would be of uncertain value. ${ }^{256}$ Indeed, it is unclear the extent to which the current set of restrictions on wraparound contracts yield benefits. That is, the revenue loss staunched by the application of investor control and the diversification requirement may not be worth the costs incurred by some to avoid these requirements, particularly when administrative and taxpayer compliance costs are also taken into account. ${ }^{257}$

While the political constraints faced by the tax agencies and the uncertain benefits to be derived from additional action point to the agencies' current lines as being sensible, investor control and the diversification requirement are problematic because they may hinder broader reform by masking the fundamental policy concerns raised by variable insurance. Investor control and diversification allow the tax agencies to "do something" when a particular iteration of the

${ }^{253}$ Telephone Interview with Andrew D. Pike, Associate Dean and Professor of Law, American University Washington College of Law (Apr. 19, 2005).

${ }^{254}$ See Schizer, supra note 9, at 1315 (describing the trend in economics literature that "us[es] the term 'frictions' to describe constraints on tax planning external to the tax law"); Daniel Shaviro, Risk-Based Rules and the Taxation of Capital Income, 50 TAX L. REV. 643, 658-59 (1995) (noting that "the use of such friction may be good or bad, depending on the ratio between deterring undesirable tax-motivated transactions on the one hand, and causing people to bear excess burden rather than pay tax on the other").

${ }^{255}$ See infra notes 265-67 and accompanying text.

${ }^{256}$ See Schizer, supra note 7, 1354-57 (describing how "modest reforms" may enhance rather than diminish the "planning option").

${ }^{257}$ See Weisbach, supra note 71 at 33 (asserting that traditional efficiency concerns in combination with administrative and compliance costs "are central to analyzing shelters"). 
wraparound insurance shelter grows large enough to draw attention to itself, such as through media coverage. ${ }^{258}$ But this agency activity will not fool the sophisticated tax avoiders using wraparound shelters and may cultivate public misperceptions about the utility of the tax benefit granted inside buildup.

This Part first examines the revenue-related rationales for the investor control doctrine and the diversification requirement, including a discussion of the relative ease with which these restrictions may be avoided. The discussion next turns to possible appearance effects created by these restrictions. Finally, this Part considers the effect of the restrictions on the prospect of broader reform.

\section{A. Revenue Effects}

The principal, revenue-related justification for the investor control doctrine and diversification requirement is prevention of conversion of ordinary income into tax-preferred income. ${ }^{259}$ For example, B, a wealthy individual, would like to invest in a hedge fund interest that will produce $\$ 100,000$ of ordinary income in a year. B is subject to a $35 \%$ tax rate and would prefer to avoid or defer the $\$ 35,000$ tax that would be due on this income. By wrapping the hedge fund interest in a variable annuity, B would realize the income economically but would not be taxed on it until it was withdrawn. The longer B can avoid withdrawing the inside buildup, the lower will be his effective tax rate. ${ }^{260}$ If the contract were a life insurance wrapper rather than an annuity, B could hold the policy until death and his beneficiary would receive the proceeds tax-free. ${ }^{261}$

Fees - part of the price for the tax shelter - will cut into B's tax benefit and hence the overall yield on the investment. B will have to pay for both variable contract fees (including mortality expenses) and any fees charged by the hedge fund. The sourcing rule of the investor control doctrine adds to the expense of the wraparound contract,

${ }^{258}$ See Schizer, supra note 9, at 1322-23 (describing political pressure to respond to press reports of taxpayer abuse).

2.99 Similar "conversion transactions" were targeted by Congress through Code section 1260 , but this Code section does not apply to insurance contracts. See id. at 1385 (describing conversion transactions and how variable insurance may be used as a substitute for derivatives).

${ }^{260}$ If he waits to withdraw the money in retirement, he may also have the advantage of being in a lower tax bracket at that time, otherwise, he could withdraw the appreciation currently through the use of a tax-free loan.

${ }^{261}$ See Schizer, supra note 6, at 1935 ("Even today, a zero rate is available with a 'life insurance wrapper' ...."). 
particularly as the switch is made from publicly available hedge funds to insurance-only funds or clones. ${ }^{262}$ Because of the imposition of the investor control sourcing rule, $\mathrm{B}$ will have to locate an insurance company (or group of insurance companies) willing to create its (or their) own hedge fund or to clone someone else's hedge fund. The costs arising from the need for insurance-only funds will likely be passed on to the contract holders, and as the cost of the tax shelter pushes down the overall investment yield, the shelter will become less attractive.

Making the wraparound insurance contract less attractive is, of course, the point behind the investor control doctrine. The costs imposed by the sourcing rule may, however, prove transitory. They are the costs of moving from a publicly available hedge fund to an insurance-only hedge fund. Once the transition is complete, the costs arising from the hedge fund component of the variable contract should not differ significantly from those found in non-insurance hedge funds. Imposition of the sourcing rule on hedge fund wrappers may even have provided the insurance companies an incentive for developing versions of the hedge fund wrapper that could be promoted to less sophisticated investors. That is, an insurance company faced with the necessity of creating insurance-only hedge funds in order to stay in the hedge fund wrapper business may begin marketing such funds as part of its mainstream offerings (assuming relevant securities registration rules are complied with), heightening the suitability concerns already present with all forms of variable insurance. The past history of insurance wrappers supports this possibility. The insurance-only requirement did not end the mutual fund wrapper; arguably, it caused an expansion in the marketing of such wrappers, albeit of insurance-only mutual funds.

Like the sourcing rule of the investor control doctrine, the diversification rule is intended to limit income conversion by making it more difficult to synthesize publicly available investments inside an insurance contract. The presence of the look-through rule for investment entities largely negates this intention. A publicly available investment, such as a mutual fund or hedge fund, may be cloned and diversification then easily satisfied through reliance on the lookthrough rule. Thus, the diversification rule does not directly affect the ability to use hedge fund wrappers, although it raises the costs of all variable contracts because insurance companies must monitor

${ }^{262}$ See Sheppard, supra note 224 , at 734 (stating that "[u]nwinding these [hedge fund wrappers] will not be cheap"). 
compliance. ${ }^{263}$ The creation of hedge fund wrappers was not touched off because the look-through rule suddenly made them attractive. Rather, when Treasury allowed unregistered partnerships to qualify automatically for the look-through rule, it created an opportunity for taxpayers to argue that the regulation trumped investor control's sourcing rule. This opportunity was valuable because it provided a technical argument that allowed insurance companies to put off the costs of creating insurance-only hedge funds. ${ }^{264}$

The glitch in the look-through regulations also allowed taxpayers the ability more easily to select their own hedge fund managers. The exception for unregistered partnerships was originally put in place apparently to allow real estate partnerships to compensate managers through the return on the managers' partnership interest. ${ }^{265}$ Similarly, managers of hedge funds frequently are compensated through ownership of a hedge fund interest offering a return different from that of other interest holders. ${ }^{266}$ The look-through exception for unregistered partnerships allowed taxpayers to wrap hedge fund interests managed by "superstars" in variable contracts without having to find a way around the more rigorous limitations on manager interests imposed on more typical investment entities underlying variable insurance, such as mutual funds. Under the recently revised regulations, managers may still hold interests in the hedge fund, but their return must be computed the same as the other interests in the fund. As one commentator on the recently revised regulations explained, "unless the Identical Computation Requirement is eliminated from the Regulations, it is likely that policyholders would be unable to access many private investment partnerships." ${ }^{267}$ Thus, the hedge fund manager compensation system may do more to slow expansion of customized, insurance-only hedge funds than the diversification rule.

${ }^{263}$ The look-through rule eases the difficulty in attaining diversification. Insurance companies may not, however, rely on representations by the underlying entity. Regulations do provide relief for inadvertent failures - at the cost of a toll charge. Treas. Reg. $\S 1.817-5(\mathrm{a})(2)$ (1989); see Stecker et al., supra note 6 (describing process of obtaining a waiver for inadvertent diversification failures).

${ }^{264}$ The argument also allowed these individuals to move easily from the derivatives used prior to the enactment of section 1260 to variable insurance. See Schizer, supra note 6, at 1935 (describing the use of wraparound insurance as hedge fund derivatives); Schizer, supra note 9, at 1385.

${ }^{265}$ See supra note 204.

${ }^{266}$ See JOHNSTON, supra note 7 , at 57 (describing hedge fund managers as charging "fat fees, sometimes taking a fifth of the investment profits for themselves").

${ }^{267}$ Tavss \& Murphy, supra note 240. 
Curtailing conversion transactions is the primary revenue-related rationale for the investor control and diversification rules. These rules, however, may also have effects at other points at which derivatives and variable insurance might intersect. ${ }^{268}$ For example, it is plausible that the investor control and diversification rules may help constrain access to annuity cash value. Although annuity withdrawals and loans do not receive the same favorable tax treatment as life insurance withdrawals and loans, variable annuity owners may be able to cash in on economic appreciation inside a contract while postponing the recognition of tax by constructing a hedge outside the contract. ${ }^{269}$ Similar techniques have been utilized in the case of stock or options held by executives subject to restrictions preventing direct sale of the securities. ${ }^{270}$ The investor control doctrine's prohibition on publicly available investments weakens a taxpayer's ability to construct outside hedges on the variable annuity's underlying assets. Nevertheless, if the underlying investment were the clone of a publicly available investment, hedging would be possible. ${ }^{271}$

In addition, any hedge of the underlying contract investments would have to be designed to take diversification into account. The derivatives market is sophisticated enough to be able to customize around the diversification requirement if sufficient information about

268 Professor Schizer has also raised the possibility that variable insurance contracts may be used to circumvent the wash-sale rules. David M. Schizer, Scrubbing the Wash Sale Rules, TAXES, Mar. 1, 2004, available at 2004 WLNR 11438288 .

${ }^{269}$ See Terrence R. Chorvat, Perception and Income: The Behavioral Economics of the Realization Doctrine, 36 CoNN. L. REV. 75, 84-85 (2003) (describing short sales against the box); Schizer, supra note 9, at 1341-42 (describing derivatives, such as short sales against the box and their substitutes, used for hedging during the 1980s and 1990s).

${ }^{270}$ See David M. Schizer, Executives and Hedging: The Fragile Legal Foundation of Incentive Compatibility, 100 CoLUM. L. REV. 440, 458 n.60 (2000). Other rules and frictions act as constraints. For example, in the case of executives' use of hedging, they are often required to post collateral to enter the transaction, and generally that collateral is best if it consists of the stock or options being hedged. Id. at 460 . In the case of variable annuities, using the annuity itself as collateral would trigger withdrawal treatment in the amount of the loan. In addition, the fees involved in the purchase of variable annuities are already quite steep. The addition of hedging transaction costs may be sufficient to make this technique less appealing. Id. at 454 (stating that there are "significant transaction costs" to hedging for executives).

271 Although Congress has enacted legislation to attack the ability of taxpayers to use hedges to lock-in investment gains without triggering tax, this legislation does not extend to hedges on appreciated variable annuity contracts. I.R.C. $\S 1259$. For a discussion of section 1259, see Schizer, supra note 9, at 1360-62. 
the underlying investments is available. ${ }^{272}$ The look-through rule may facilitate access to this information since diversification may be satisfied by looking-through to the assets of mutual funds and partnerships, which may be clones of publicly available mutual funds or partnerships. The availability of derivatives for use in hedging mutual fund or partnership interests (including hedge fund interests) is well-established. ${ }^{273}$

The effect of the substance-over-form standard of the investor control doctrine is less clear than that of the sourcing and diversification rules. ${ }^{274}$ Given the disregard aggressive taxpayers showed for the public investment prohibition, it is possible such taxpayers simply ignore the standard, except that they would try to avoid the appearance of collusion and the exercise of outright control over underlying contract assets. ${ }^{275}$ For example, in the case of the hedge fund wrappers, care might be taken not to hold interests in the same hedge fund both inside and outside a variable insurance contract. ${ }^{276}$

Although the investor control doctrine and the diversification requirement may halt some conversion transactions and - more speculatively - curtail tax-free access to annuity cash value, it is not known whether the benefits are worth the cost of these anti-shelter provisions. ${ }^{277}$ Because investor control and diversification do not shut

${ }^{272}$ See Frank Partnoy, Enron and the Derivatives World, in ENRON: CORPORATE Fiascos AND Their IMPLiCATIONS 169, 170 (Nancy B. Rapoport \& Bala G. Dharan eds., 2004) ("Recent estimates of the size of the exchange-traded derivatives market ... are in the range of $\$ 13$ to $\$ 14$ trillion in notional amount. By contrast, the estimated notional amount of outstanding OTC derivatives as of year-end 2000 was $\$ 95.2$ trillion. And that estimate is most likely an understatement.").

${ }^{273}$ See Schizer, supra note 6, at 1888.

274 There is considerable debate over the extent to which such substance-overform standards in general affect taxpayer behavior. See, e.g., Joseph Bankman, The Economic Substance Doctrine, 74 S. CAL. L. REV. 5 (2000); David Hariton, Sorting Out the Tangle of Economic Substance, 52 TAX LAW. 235 (1998); Daniel Shaviro, Economic Substance, Corporate Tax Shelters \& the Compaq Case, 88 TAX NoTEs 221 (July 10, 2000). sharing.

${ }^{275}$ In tension with this standard is securities law's emphasis on information-

${ }^{276}$ The 2002 investor control private letter ruling contained a representation to that effect as did Revenue Ruling 2003-92. I.R.S. Priv. Ltr. Rul. 2002-44-001 (May 2, 2002); Rev. Rul. 2003-92, 2003-2 C.B. 350.

${ }^{277}$ See Shaviro, supra note 254 , at 654 (describing the tax system dealing with financial assets as "almost a textbook description of a system that, with respect to affected transactions, generates far less tax revenue than socially wasteful excess burden."). It is difficult to measure whether efficiency has been achieved. See also 
down wraparound insurance completely, some taxpayers will incur costs to avoid these requirements. ${ }^{278}$ Costs must also be incurred by taxpayers who wish to comply with these requirements, particularly the diversification requirement. Finally, the requirements may increase the marketing of insurance-only hedge funds as a result of the new certainty in this area. ${ }^{279}$ Thus, as occurred following the issuance of the mutual fund wrapper ruling, perhaps even more taxpayers will invest in "good" insurance wrappers, thereby sheltering more revenue through these products than would otherwise occur.

\section{B. Fairness Effects}

Governmental responses to tax shelters are often as much about meeting fairness concerns as they are about revenue - providing assurance that the system is not skewed in favor of the wealthy. This has been the case with the agency responses to wraparound insurance. First, the timing of the agency activity has been correlated with media accounts about the use of wraparound insurance as a tax shelter, suggesting that agency activity has been in part motivated by public perception of wraparound insurance. In addition, the tax agencies have issued press releases announcing their activities as belonging to part of their anti-tax shelter stance. Finally, the substance of investor control and diversification create fairness effects, but because of the ease with which these requirements may be avoided, these effects may be more illusory than real. Because the wraparound insurance shelter grows from a statutory tax subsidy, however, the periodic weeding-out efforts by the agencies have, out of necessity, left the root of the shelter untouched.

The history of wraparound insurance products reveals a correlation between the appearance of mainstream media reports and agency response. ${ }^{280}$ With respect to the investment annuity in particular, the agencies seem genuinely not to have understood the tax shelter implications of the product until active marketing by insurance

Schizer, supra note 7 , at $1357-58$ (noting that "it is hard to generalize about efficiency" and arguing for the importance of obtaining "empirical judgments"); Shaviro, supra note 254, at 684 (describing the difficulties of evaluating tax changes "without better empirical information about revenue effects and transactions costs").

278 Weisbach, supra note 71 , at 32-33 (describing how in the face of changes to tax shelter rules, "some individuals will choose to continue sheltering... [because] the additional cost will be worth the tax savings").

${ }^{279}$ See Gergen \& Schmitz, supra note 4.

280 See supra Parts III.B-D \& F. 
companies triggered mainstream media coverage. ${ }^{281}$ In the case of the savers' annuity and mutual fund wrapper, however, media coverage may have served more to measure the degree of sheltering than as a source of new revelations. That is, the tax agencies may have relied (perhaps even unconsciously) on mainstream media coverage as an indicator that the shelter had once again become actively marketed and more widely accessible and, therefore, that further agency action was required.

The earlier wraparound products grew while the agencies were at the beginning stages of developing an understanding of new insurance products, including not just variable insurance but also universal life insurance. This period culminated in strong Treasury recommendations to Congress to end the deferral for inside buildup as part of reform efforts during the mid-1980s. Congress did not end the subsidy, and although various subsequent administrations have supported proposals to curtail the benefit, the current prospect of fundamental reform in this area is low. In the time period since Congress last took a serious look at inside buildup, the increasing sophistication of derivative products and the development of the hedge fund industry have made this subsidy more problematic.

The most recent agency effort to control wraparound insurance occurred against this backdrop - a long agency history of dealing with wraparound insurance revealing the shortcomings of investor control and diversification, low prospects for broader reform, and the emergence of more sophisticated means of using the old wraparound shelter. As media coverage increased about the coupling of hedge funds and insurance companies, pressure to respond also grew. Further, insurance companies marketing hedge fund wrappers could point to a Treasury regulation as technical support for their position. Yet even after revocation of this regulation, the technique could continue through the use of clones or through derivatives wrappers, which may be the next type of wraparound insurance shelter to emerge. In this context, the agency action taken against hedge fund wrappers, while arguably as helpful as earlier action, seems primarily aimed at allaying, in the short term, concerns about fairness. Of course, preserving system fairness is an important tax agency role, but some tax agency efforts in this regard seem more cynical than others.

Investor control and diversification ensure that the investment inside a variable contract does not - superficially at least - look the same as one existing outside a contract. The inability to hold an 
identical investment both inside and outside an insurance contract helps cultivate the impression that there is something differentiating the investments underlying variable insurance from other investments that makes them deserving of congressional largesse - that horizontal equity is not violated by these products. ${ }^{282}$ By the time of the hedge fund wrapper rulings, the agencies' experience with derivatives must, however, have made it clear that such differentiation is not possible. Yet, there is no hint of the limitations facing the tax agencies apparent in their press releases surrounding these rulings.

Investor control and diversification also hold out the promise that wealthy individuals will not be able to customize, ${ }^{283}$ but these requirements at most make customization more expensive. ${ }^{284}$ Changes to the diversification regulations have also made it more difficult for owners to compensate hedge fund managers, but new ways of compensating these managers may be developed, and the increased expense may only be temporary as insurance companies turn to insurance-only hedge fund clones or possibly to derivatives wrappers as substitutes for the hedge fund wrapper.

Investor control and diversification may also cause confusion about the suitability of variable insurance for less wealthy taxpayers. The provision of adequate counseling on suitability by brokers selling variable insurance has been a perennial concern. ${ }^{285}$ The

${ }^{282}$ It has been suggested that Congress already has decided - through the legislation enacted in the $1980 \mathrm{~s}$ - that it is only concerned about appearance. Richard Skillman, a tax practitioner who as served as Deputy Chief Counsel and as Acting Chief Counsel at the Service, has argued: "[W]hile the legislative history of section $817(\mathrm{~h})$ indicates that Congress viewed it as generally inappropriate for taxpayers to use variable contracts to obtain interests in 'publicly available' investments, the congressional policy concerns may have been rooted in appearance more than economic substance ...." Skillman, supra note 225.

${ }^{283}$ Distributional effects are associated with vertical equity. See SLEMROD \& BAKIJA, supra note 7, at 58 ("[W]e deal with the divisive issue of vertical equity or, in other words, the appropriate degree of tax progressivity."); Weisbach, supra note 14 , at 1647 ("An alternative formulation of vertical equity is simply a concern with the distributional impact of taxes.").

${ }^{284}$ The ability to place private placement hedge funds inside customized insurance wrappers may have provided the holders of such contracts with personal satisfaction derived from ownership of prestige symbols. Just as retail versions of the mutual-fund wrapper have become commonplace, retail hedge fund wrappers may become more "common" as a result of recent investor control activity. This might render hedge fund wrappers less attractive, to the extent they were selected as status symbols, or it may simply cause the wealthiest individuals to find a new, elite wraparound technique.

${ }^{285}$ See, e.g., Dismissal of Variable Annuity Class Action Was Proper, 91 TAX 
representation by the tax agencies that variable insurance is now fairer because of the removal of hedge fund wrappers may foster the illusion that taxpayers derive equal benefit from the tax deferral granted to the variable insurance inside buildup. Since the general lack of understanding about the beneficiaries of the tax subsidy for inside buildup is already high, ${ }^{286}$ the impact of investor control rulings and revised diversification regulations may be small. The possible availability of mainstream, insurance-only hedge fund wrappers may, however, exacerbate suitability concerns, and the rulings certainly do not help promote understanding about the general fairness of the tax treatment for insurance products.

\section{Prospects for Reform}

Press coverage of the wraparound insurance tax shelter has receded since the issuance of the new rulings and revised regulations. The most recent agency activity with respect to wraparound insurance may have brought about a temporary lull in the shelter, or it may be that new iterations are being devised and marketed to such a small group of individuals that it has not yet received attention. ${ }^{287}$ The shelter seems, however, almost certain to reappear given the relative ease with which investor control and diversification may be circumvented.

The tax agencies could lessen the attractiveness of using wraparound insurance in conversion transactions by further increasing the burden imposed on these transactions. The Code provides the agencies significant authority to deal with the issue of wraparound insurance. ${ }^{288}$ The agencies might, for example, develop rules about the allowable number of underlying investments and of changes between

NOTES $1875,1875-76$ (June 11, 2001) (describing dismissal of class action alleging unfair practices in company advising on appropriateness of variable contracts).

${ }^{286}$ See supra Part II.C.

287 Other factors also play an important role in the attractiveness of this tax shelter. For example, low tax rates generally make sheltering less popular. The fee structure and mortality charges for variable insurance may also help keep this particular shelter in check because there may be cheaper substitute shelters. The inability to deduct losses sustained inside a variable contract may also play a role in constraining some wraparound insurance schemes. Schizer, supra note 6, at 1936 ("A provocative implication... is that [hedge fund wrappers] do not require special attention.... Whereas gains are not taxed, losses are not deductible.").

288 But see Alexander, supra note 88 (asserting, "[p]ut simply, we believe current law imposes significant restrictions on the ability of the Service to further limit the availability of deferred variable annuity contracts."). 
underlying investments during the year. ${ }^{289}$ The agencies could prohibit segregated asset accounts from directly investing in clones of publicly available investments, and they may also be able to prohibit underlying investments that are substantially similar to publicly available investments. ${ }^{290}$ The agencies could also eliminate lookthrough altogether for partnerships since the Code mandates lookthrough treatment only for mutual funds and trusts. ${ }^{291}$

No single one of these options is certain to end the technique, ${ }^{292}$ and they would be of uncertain benefit because of increased costs, whether incurred by taxpayers in complying with (or avoiding) the new rules or by the agencies in monitoring for complex synthetic arrangements. If the agencies were to prohibit allocations to clones of publicly available investments, for example, taxpayers could blend two clones in known percentages - that is, hedge fund $\mathrm{A}$ as $40 \%$ of the combined fund and hedge fund $\mathrm{B}$ as $60 \%$. Additionally, if the agencies prohibited look-through for partnerships, a fund might be created to hold derivatives of publicly available hedge funds. ${ }^{293}$

Hesitancy over further burdening wraparound insurance may also

${ }^{289}$ See Thompson, supra note 20 , at 520 (explaining that "the Internal Revenue Service has issued warnings that too much investment choice in a deferred variable annuity might result in unfavorable tax treatment, but it never issued regulations quantifying its precise position ...."). But see Alexander, supra note 88.

290 As described supra Part III.E.3, legislative history for section 817 warns against this. Professor Schizer has argued that Treasury has authority under section 1260 to reach this result. See Schizer, supra note 9, at 1389. However, as he acknowledges, section 1260 specifically applies only when ordinary income is converted to "long term capital gain." Id. at $1389 \&$ n.289. In the case of annuities and life insurance, ordinary income is being converted to inside buildup, which receives tax deferral. It is taxed at ordinary income rates when it is withdrawn.

${ }^{291}$ In addition to these substantive measures, the agencies could have also applied retroactivity more stringently to their investor control rulings.

${ }^{292}$ Cf. Schizer, supra note 9, at 1385 (asserting that "Treasury arguably has the necessary regulatory authority under current law" to end conversion transactions that make use of variable insurance contracts).

${ }^{293}$ It would have to meet the diversification test, so at least five investments representing five different issuers would be required. It is unclear who the issuer would be in the case of derivatives. The Service has held in a private letter ruling that the issuer of a repurchase agreement was the broker rather than the issuer of the underlying securities. I.R.S. Priv. Ltr. Rul. 91-25-038 (Mar. 27, 1991); cf. I.R.S. Gen. Couns. Mem. 39,708 (Mar. 14, 1988) (concluding that the issuer of stock index options or futures for purposes of the RIC diversification rules "are issuers of the stocks underlying the index"). If, however, the issuer of a derivative were considered to be the same as that of a publicly available investment, then the investor control doctrine should still operate to prohibit such a structure. 
be warranted by the fact that were the tax agencies to impose additional restrictions on the insurance industry, the industry would likely respond as it has in the past to encroachment - with an aggressive lobbying campaign. ${ }^{294}$ Such a lobbying campaign could even result in the creation of further unjustifiable benefits for insurance rather than congressional involvement leading to broader reform. Investor control and diversification may thus be viewed as the terms of an uneasy pact between the insurance industry and the agencies under which the insurance industry is subjected to the relatively minimal burdens imposed by these requirements, and the agencies are able to continue asserting some control over the wraparound insurance technique.

While the agencies' decision not to disrupt this stability is sensible, their actions may also reduce the possibility that fundamental reform in this area will take place. As described in the preceding section, the ability of the tax agencies to respond to media coverage with investor control and diversification may cause casual observers to believe that more has been accomplished than actually has been. The agencies could mitigate this possibility by providing more information about the limitations on reaching wraparound insurance and about the tax benefits of all cash value insurance in general. To be sure, the limitations of investor control and diversification are already discussed in the mainstream financial press, though primarily by the insurance industry and its representatives. In addition, non-tax regulators, such as the SEC and the National Association of Securities Dealers (NASD), have expressed concern about whether insurance brokers adequately discuss suitability, including tax consequences, with potential contract holders of variable contracts. A clear message from the tax agencies about the limitations of investor control and diversification could help the public make better sense of both the comments from the insurance industry and the concerns of non-tax regulators.

The "arcaneness" 295 of variable insurance taxation would, however, affect the extent to which the agencies could successfully inform the taxpayer about the interplay of agency action and statutory constraint. It is easier to impart the message that the tax agencies have "done something" to make insurance products fairer than to

${ }^{294}$ See supra notes 58, 293 and accompanying text.

295 See SHAviro, supra note 15, at 87 (describing how tax politics are hindered "in the informational realm. An initial problem is simply the arcaneness of determining what would be, say, neutral treatment of competing instruments."). 
explain the limitations on the reach of that activity. ${ }^{296}$ Further, the agencies may be averse to exposing their limitations to the public. ${ }^{297}$ There is, for example, some evidence that lack of confidence in the fairness of the tax system may trigger noncompliance, and that taxpayers may increase compliance if they perceive that the system is operating fairly. ${ }^{298}$

A more feasible approach to obtaining support for broad reform may be to appeal to Congress directly. ${ }^{299}$ During the early 1980s, Treasury urged comprehensive reforms in the area of insurance, including the full taxation of inside buildup on cash value life insurance. ${ }^{300}$ Although this particular reform was not enacted, some legislative restrictions on cash value insurance products were

${ }^{296}$ Cf. Schizer, supra note 9, at 1321 ("For sophisticated transactions, average taxpayers could well be fooled in this way for some period of time, but eventually they are likely to learn the truth, for instance, through media coverage of avoidance.").

In the estate tax area, there is widespread support for repeal although it affects only a limited number of individuals. This disparity may be caused by a combination of rational ignorance and optimism bias. See Lee Ann Fennell, Death, Taxes and Cognition, 81 N.C. L. REV. 567 (2003); see also JoHNSTON, supra note 7, at 71-91 (describing misperceptions about the application of the estate tax and ascribing them in part to deliberate campaigns to misinform).

${ }^{297}$ See Michael S. Kirsch, Alternative Sanctions and the Federal Tax Law: Symbols, Shaming, and Social Norm Management as a Substitute for Effective Tax Policy, 89 IOWA L. REV. 863 (2004); Schizer, supra note 9, at 1321 (describing symbolic benefits that may emerge from "even relatively ineffective efforts to curtail planning"); see also Shaviro, supra note 254, at 700 (discussing how certain transactions may "as an aesthetic matter ... excite hostility from defenders of the tax system - notwithstanding that one may accomplish but little ... if taxpayers, with sufficient ease, can achieve a favorable result by structuring slightly differently").

298 See Leandra Lederman, The Interplay Between Norms and Enforcement in Tax Compliance, 64 OHIO ST. L.J. 1453, 1484-99 (discussing evidence suggesting that publicity about certain types of tax avoidance or tax enforcement may affect taxpayer compliance); Stephen W. Mazza, Taxpayer Privacy and Tax Compliance, 51 U. KAN. L. REV. 1065, 1078 (2003) (discussing survey evidence showing "that deterrence messages communicated through mass media are related to increased perceptions of detection and punishment for tax evasion"); John T. Scholz, Comment on Carrots and Sticks in Enforcement, in THE CRISIS IN TAX ADMINISTRATION 258, 261-62 (Henry J. Aaron \& Joel Slemrod eds., 2004) (discussing plausibility of a model in which "taxpayers obey the terms of an implicit tax contract as long as other taxpayers and the government meet their expected roles").

${ }^{299}$ This assumes that the current administration is amenable to Treasury taking such a role.

300 See Birnbaum \& MURRAY, supra note 56, at 57, 84-85 (describing Treasury proposals to tax inside buildup). 
implemented. ${ }^{301}$ It is likely not politically possible to obtain full repeal of the tax deferral for inside buildup on all cash value life insurance and annuities. ${ }^{302}$ It may, however, be more viable to obtain reforms aimed only at variable insurance. ${ }^{303}$

For example, variable contract holders could be taxed as though they had purchased the underlying investment and a fixed, cash value life insurance contract or annuity earning the risk-free rate of return. Deferral of tax could continue on that portion representing the riskfree rate. ${ }^{304}$ Bifurcation approaches such as this would raise complexity concerns; however, insurance companies likely already have the necessary administrative mechanisms in place since the funds underlying variable contracts are essentially treated as separate tax entities whose tax items flow to the insurance companies rather than to the contract holders. An even less drastic alternative would be to impose annual contribution limits on variable contracts such as those in place for other types of tax-preferred retirement products (e.g., 401(k) plans). ${ }^{305}$

In conjunction with direct appeals to Congress, the agencies could use deliberate inaction to focus legislative attention on the problem of variable insurance taxation. This is not to suggest that the agencies should abdicate their responsibilities to "apply[] the tax law with integrity and fairness to all." ${ }^{306}$ To the contrary, it would require that they signal the need for broader reform and time such signals to follow media coverage about the newest wraparound shelter iteration. Press attention on wraparound insurance could be met by the tax agencies not with new investor control rulings but with statements about the necessity of congressional intervention in this area. Media pressure has been effective in the past at motivating Congress. ${ }^{307}$

${ }^{301}$ See supra Part III.E.

${ }^{302}$ See Thompson, supra note 20, at 525-26 (discussing likelihood that Congress would take specific action to constrain variable annuities).

${ }^{303}$ Id. at 508-26 (suggesting a course of possible congressional action).

${ }^{304} C f$. Cunningham \& Schenk, supra note 6, at 735 (urging that all investment assets be subject to tax on at least the risk-free rate of return).

${ }^{305}$ But see Thompson, supra note 20, at 517-18 (arguing that the "recurring proposal" of placing limits on allowable contributions is "probably not sound policy").

306 The IRS Mission, 1998-44 I.R.B. 2.

307 See Schizer, supra note 9, at 1343 \& n.101 (describing how Code section 1259, which applies a constructive sale rule to certain hedging transactions, was enacted in response to a highly publicized case involving the Estee Lauder family); Daniel Shaviro, Beyond Public Choice and Public Interest: A Study of the Legislative Process as Illustrated by Tax Legislation in the 1980s, 139 U. PA. L. REv. 1, $24-27$ (1990) 
With respect to hedge fund wrappers, for example, it may have been more effective for the tax agencies to have taken a more minimalist approach. At the time the hedge fund investor control ruling was issued, there were not only press reports about wraparound insurance products but also reports about other avoidance techniques involving hedge funds and insurance. ${ }^{308}$ Securities law issues involving variable insurance and hedge fund were also increasingly being raised in the financial press. Strategic inaction on the part of the tax agencies - in combination with the atmosphere of concern about variable insurance and hedge funds - may have prompted Congress to intervene. Instead, the tax agencies deflected the attention of the financial press from Congress to themselves through their rulemaking actions.

\section{CONCLUSION}

The history of wraparound insurance reveals a cat-and-mouse game typical of tax shelters. Just as in the cartoons of this genre, the cat appears doomed always to be one step behind. Congressional action removing the differential treatment for variable insurance inside buildup is required to end this particular chase. This article suggests that a course of minimalist response to new iterations of the wraparound insurance shelter, combined with proposals for broadbased reform, may be the best avenue for the tax agencies to bring about such legislative change.

(describing influence of media on reform in the 1980s).

${ }^{308}$ See JOHNSTON, supra note 7, at 57-58 (discussing tax avoidance techniques involving hedge funds and insurance). 
HeinOnline -- 25 Va. Tax Rev. 200 2005-2006 